\title{
Optimized culture conditions for bacterial cellulose production by Acetobacter senegalensis MA1
}

\author{
K. Aswini, N. O. Gopal and Sivakumar Uthandi ${ }^{*}$ (D)
}

\begin{abstract}
Background: Cellulose, the most versatile biomolecule on earth, is available in large quantities from plants. However, cellulose in plants is accompanied by other polymers like hemicellulose, lignin, and pectin. On the other hand, pure cellulose can be produced by some microorganisms, with the most active producer being Acetobacter xylinum. A. senengalensis is a gram-negative, obligate aerobic, motile coccus, isolated from Mango fruits in Senegal, capable of utilizing a variety of sugars and produce cellulose. Besides, the production is also influenced by other culture conditions. Previously, we isolated and identified A. senengalensis MA1, and characterized the bacterial cellulose (BC) produced.

Results: The maximum cellulose production by A. senengalensis MA1 was pre-optimized for different parameters like carbon, nitrogen, precursor, polymer additive, pH, temperature, inoculum concentration, and incubation time. Further, the pre-optimized parameters were pooled, and the best combination was analyzed by using Central Composite Design (CCD) of Response Surface Methodology (RSM). Maximum BC production was achieved with glycerol, yeast extract, and PEG 6000 as the best carbon and nitrogen sources, and polymer additive, respectively, at $4.5 \mathrm{pH}$ and an incubation temperature of $33.5^{\circ} \mathrm{C}$. Around $20 \%$ of inoculum concentration gave a high yield after 30 days of inoculation. The interactions between culture conditions optimized by CCD included alterations in the composition of the $\mathrm{HS}$ medium with $50 \mathrm{~mL} \mathrm{~L}^{-1}$ of glycerol, $7.50 \mathrm{~g} \mathrm{~L}^{-1}$ of yeast extract at $\mathrm{pH} 6.0$ by incubating at a temperature of $33.5^{\circ} \mathrm{C}$ along with $7.76 \mathrm{~g} \mathrm{~L}^{-1}$ of PEG 6000 . This gave a $\mathrm{BC}$ yield of wet weight as $469.83 \mathrm{~g} \mathrm{~L}^{-1}$.

Conclusion: The optimized conditions of growth medium resulted in enhanced production of bacterial cellulose by $A$. senegalensis MA1, which is around 20 times higher than that produced using an unoptimized HS medium. Further, the cellulose produced can be used in food and pharmaceuticals, for producing high-quality paper, wound dressing material, and nanocomposite films for food packaging.
\end{abstract}

Keywords: Bacterial cellulose, Acetobacter senegalensis, Optimization, RSM

\section{Background}

Cellulose is a water-insoluble substance that is commonly found in plant cell walls, especially in the stalk, stem, branches, and woody parts of the plant network. The production of cellulose in nature is about $10^{11}-10^{12}$

\footnotetext{
* Correspondence: usivakumartnau@gmail.com

Biocatalysts Laboratory, Department of Agricultural Microbiology, Tamil Nadu Agricultural University, Coimbatore, Tamil Nadu 641003, India
}

tons per year [1]. Cellulose, due to its abundance, has been recognized as an inexhaustible raw material to meet the demand for eco-friendly and biocompatible use [2]. The utilization of easily available raw materials such as sugarcane bagasse, banana, paddy straw, etc., can serve as an alternative source for the production of cellulose derivatives and helps to minimize deforestation [3]. On the other hand, $\mathrm{BC}$ is an excellent alternative to plant cellulose, which can be used for manufacturing

(c) The Author(s). 2020 Open Access This article is licensed under a Creative Commons Attribution 4.0 International License, which permits use, sharing, adaptation, distribution and reproduction in any medium or format, as long as you give appropriate credit to the original author(s) and the source, provide a link to the Creative Commons licence, and indicate if changes were made. The images or other third party material in this article are included in the article's Creative Commons licence, unless indicated otherwise in a credit line to the material. If material is not included in the article's Creative Commons licence and your intended use is not permitted by statutory regulation or exceeds the permitted use, you will need to obtain permission directly from the copyright holder. To view a copy of this licence, visit http://creativecommons.org/licenses/by/4.0/ The Creative Commons Public Domain Dedication waiver (http://creativecommons.org/publicdomain/zero/1.0/) applies to the data made available in this article, unless otherwise stated in a credit line to the data. 
high-end cellulose-based products [4]. BC is produced by various species of bacteria, such as Gluconacetobacter (formerly Acetobacter), Agrobacterium, Aerobacter, Achromobacter, Azotobacter, Rhizobium, Sarcina and Salmonella, with the most efficient producer being Gram-negative, acetic acid bacteria, A. xylinum [5]. Other cellulose producing bacteria can also be distinguished depending upon their source of carbon [6]. In nature, Gluconacetobacter xylinus forms biofilms of cellulose on the surface of fruits and flowers [7]. Intriguingly, G. xylinus strains, which are known to be efficient producers of bacterial cellulose, can also produce $\beta$-glucosidase [8]. A thermotolerant acetic acid bacterium, isolated in Senegal from mango fruit (Mangifera indica), was also found to produce cellulose [9]. Also, Gluconacetobacter kombuchae RG3T, isolated from Kombucha tea, displays both cellulose-producing and nitrogen-fixing characteristics [10]. The strain, Enterobacter amnigenus $\mathrm{GH}-1$, was subjected to various natural carbon sources like molasses, starch hydrolysate, sugar cane juice, coconut water, coconut milk, pineapple juice, orange juice, and pomegranate juice for growth and cellulose production [11]. Bacterial cellulose microfibrils from non-conventional sources such as agroindustrial residues of pineapple peel and sugar cane juice were produced by Gluconacetobacter swingsii [12]. Batch fermentations with the bacterial strain Komagataeibacter sucrofermentans using commercial sugars, and crude glycerol were also found to produce the extracellular polysaccharide [13]. The $\mathrm{BC}$ produced from the Egyptian Achromobacter sp. had pure structure without any other impurities [14].

Due to $\mathrm{BC}$ structure that consists of only glucose monomer, it exhibits numerous excellent properties such as unique nanostructure [15], high water holding capacity [16], a high degree of polymerization [17], high mechanical strength [12], and high crystallinity [18]. Owing to its high water holding capacity and tensile strength, microbial cellulose has become an essential raw material for products such as high fidelity acoustic speakers, papers, and dessert foods [19]. Also, BC has been used in the production of pharmaceutical and cosmetic products [20]. Nevertheless, the high production cost, primarily due to ingredients of the medium, is the major obstacle to its wide application. The critical factors affecting the $\mathrm{BC}$ production include the fermentation composition, i.e., carbon, nitrogen, and mineral sources used in the medium [21] and the operating conditions such as $\mathrm{pH}$, temperature [22], and dissolved oxygen of the medium [23], inoculation ratio [24], and inoculum age. Though many investigators have reported BC production by various Acetobacter spp., the yield could not be improved to a considerable level. In order to enhance the $\mathrm{BC}$ yield, the present study was aimed at determining the optimum conditions viz., carbon, nitrogen, $\mathrm{pH}$, temperature, precursor, polymer additives, inoculum concentration, and incubation period for achieving maximum cellulose production by $A$. senegalensis MA1. Response Surface Methodology (RSM) performed by using Central Composite Design (CCD) was used to optimize various fermentation parameters.

\section{Results}

Pre-optimization of culture conditions for cellulose production by $A$. senegalensis MA1

The optimum fermentation conditions, viz., carbon, nitrogen, $\mathrm{pH}$, temperature, precursor and polymer additives, were investigated by measuring the wet and dry weights of the $\mathrm{BC}$ mats for maximum production by $A$. senegalensis MA1, and the results are discussed hereunder.

\section{Nutrient sources on $\mathrm{BC}$ production}

BC production by $A$. senegalensis MA1 was evaluated by supplementing with 24 carbon sources, 14 nitrogen sources, different concentrations of UDP-Glucose (from 10 to $100 \mathrm{ppm}$ ), and 12 additives. Among the sources of carbon used, glycerol produced a maximum BC with a wet weight of $248 \mathrm{mg} \mathrm{mL}^{-1}$, yielding a dry weight of 13 $\mathrm{mg} \mathrm{mL}^{-1}$ in HS broth (Fig. 1). This was followed by tryptose and fructose, which produced wet weight of $114 \mathrm{mg} \mathrm{mL}^{-1}$ and $100 \mathrm{mg} \mathrm{mL}^{-1}$ and dry weight of 6.54 $\mathrm{mg} \mathrm{mL}^{-1}$ and $6.17 \mathrm{mg} \mathrm{mL}^{-1} \mathrm{BC}$, respectively. It was also observed that the carbon sources, viz., acetic acid, galactose, glycine, lactic acid, malic acid, mannose, oxalic acid, starch, and xylitol did not result in the production of cellulose. There was no significant difference in the wet weight of BC produced from glucose, mannitol, sorbitol, and succinic acid.

Among the nitrogen sources used (at $0.5 \%$ concentration), yeast extract produced a maximum wet weight of $522 \mathrm{mg} \mathrm{mL}^{-1}$ yielding $52.26 \mathrm{mg} \mathrm{mL}^{-1}$ dry weight of BC in HS broth. Next to yeast extract, the beef extract produced $105 \mathrm{mg} \mathrm{mL}^{-1}$ wet weight yielding $1.89 \mathrm{mg} \mathrm{mL}^{-1}$ dry weight of $\mathrm{BC}$ followed by peptone, registering 100 $\mathrm{mg} \mathrm{mL}^{-1}$ wet and $1.49 \mathrm{mg} \mathrm{mL}^{-1}$ dry weight. Moreover, $\mathrm{BC}$ production was not supported by nitrogen sources like ammonium nitrate, calcium nitrate, sodium azide, sodium nitrate, and urea (Fig. 2).

At different concentrations of UDP-Glucose (10 to $100 \mathrm{ppm}$ ), the maximum wet weight and dry weight of $\mathrm{BC}\left(81 \mathrm{mg} \mathrm{mL}^{-1}\right.$ and $5.27 \mathrm{mg} \mathrm{mL}^{-1}$ in HS broth, respectively) were produced with $100 \mathrm{ppm}$ of UDPGlucose (Fig. 3). Instead, there were no significant differences in the wet and dry weight of the $\mathrm{BC}$ produced from other concentrations. Since UDP-Glc is the precursor for $\mathrm{BC}$ biosynthesis, it was used to confirm the influence of its exogenous supply over the production. 


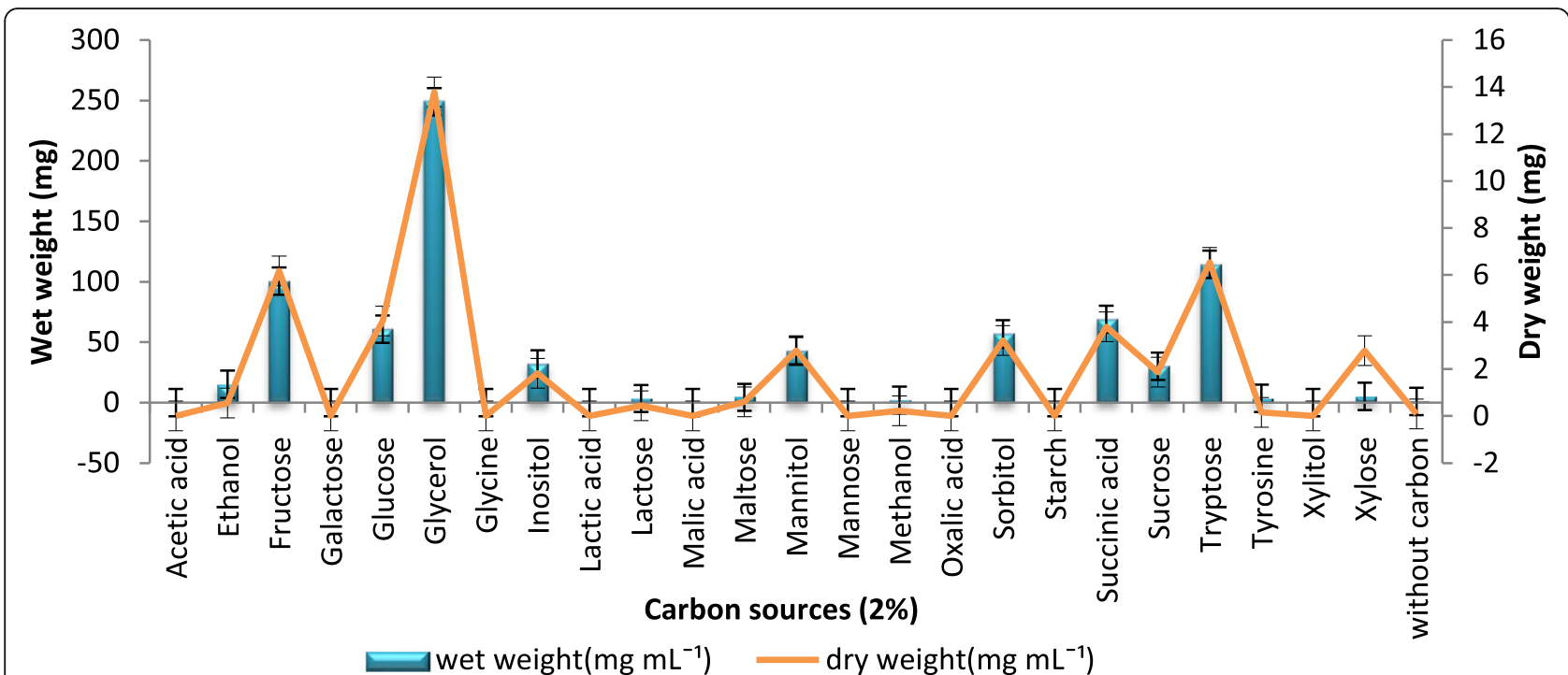

Fig. 1 Effect of different carbon sources on BC production: BC production using different carbon sources. Rectangular bars denote the wet weight of $B C$ produced by $A$. senegalensis $M A 1$ and line denotes the dry weight, both provided with the error bars representing the variability of the reported measurement

Of the 12 different additives (at 1\%) evaluated for the $\mathrm{BC}$ production, the addition of PEG 6000 recorded a maximum of $84 \mathrm{mg} \mathrm{mL}^{-1}$ wet weight and $6.65 \mathrm{mg} \mathrm{mL}^{-1}$ dry weight of BC. The addition of lignin, xylan, carboxymethylcellulose, pectin, chitin, agar, and gelatin yielded $67,64,52,52,49,48$, and $44 \mathrm{mg} \mathrm{mL}^{-1}$ of wet BC in HS broth, respectively (Fig. 4), which was even lesser than the control that did not receive any additives. The least BC production of $16 \mathrm{mg} \mathrm{mL}^{-1}$ wet weight and $2.51 \mathrm{mg}$ $\mathrm{mL}^{-1}$ dry weight was observed with the additive agarose.

\section{Environmental parameters on $\mathrm{BC}$ production}

The $\mathrm{pH}$ values of 2.0,3.0, 4.0, and 9.0 showed no $\mathrm{BC}$ production. The maximum $\mathrm{BC}$ production was at $\mathrm{pH}$ 4.5 with a wet weight of $98 \mathrm{mg} \mathrm{mL}^{-1}$ and a dry weight of $6.44 \mathrm{mg} \mathrm{mL}^{-1}$, followed by $\mathrm{pH} 5.0$, which produced $85 \mathrm{mg} \mathrm{mL}^{-1}$ wet weight and $5.48 \mathrm{mg} \mathrm{mL}^{-1}$ dry weight of $\mathrm{BC}$ in $\mathrm{HS}$ broth. At $\mathrm{pH} 5.5$, wet weight of $61 \mathrm{mg} \mathrm{mL}^{-1}$ and $4.74 \mathrm{mg} \mathrm{mL}^{-1}$ dry weight of $\mathrm{BC}$ was produced (Fig. 5). Further increase in $\mathrm{pH}$ reduced the amount of $\mathrm{BC}$ production. There was no

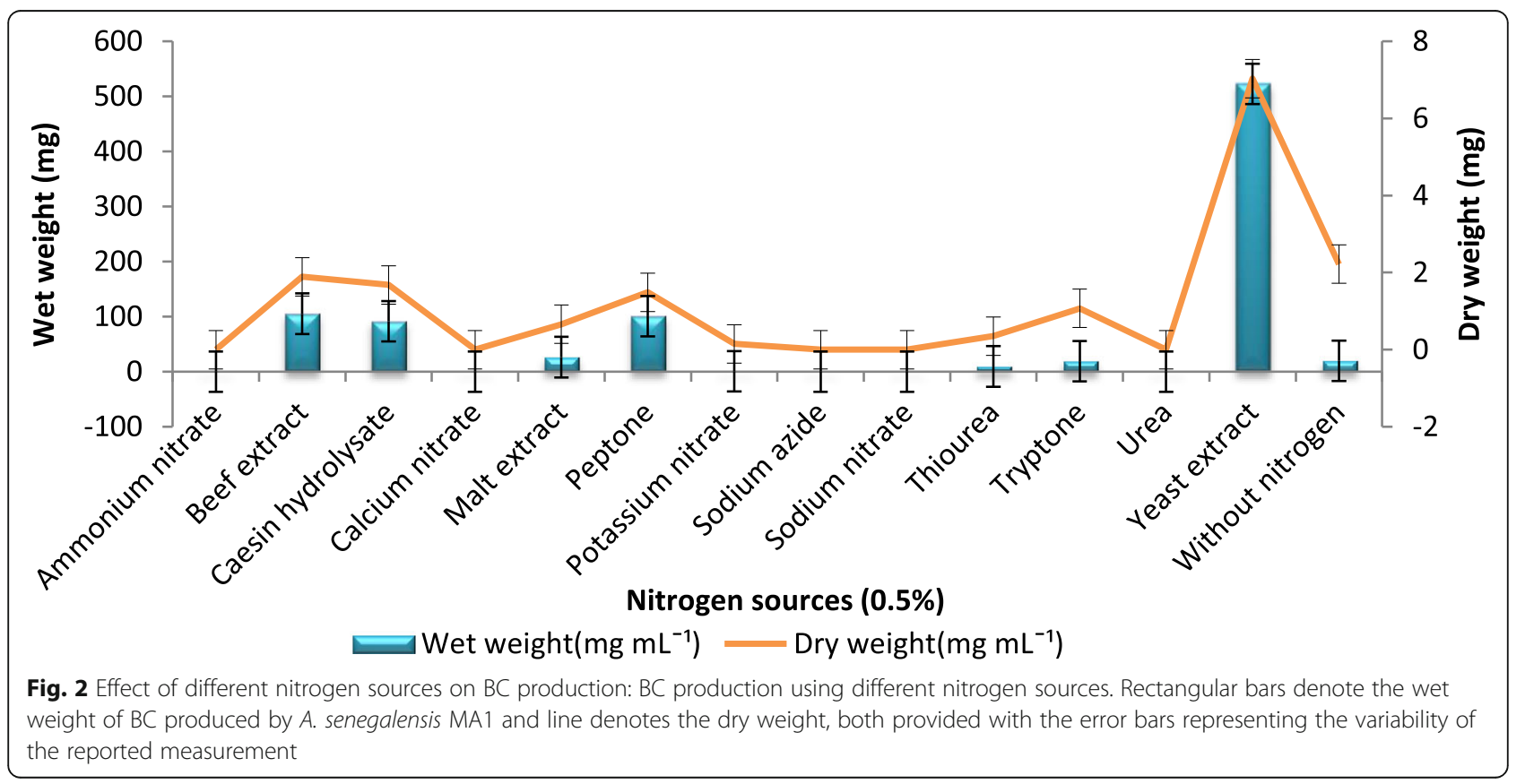




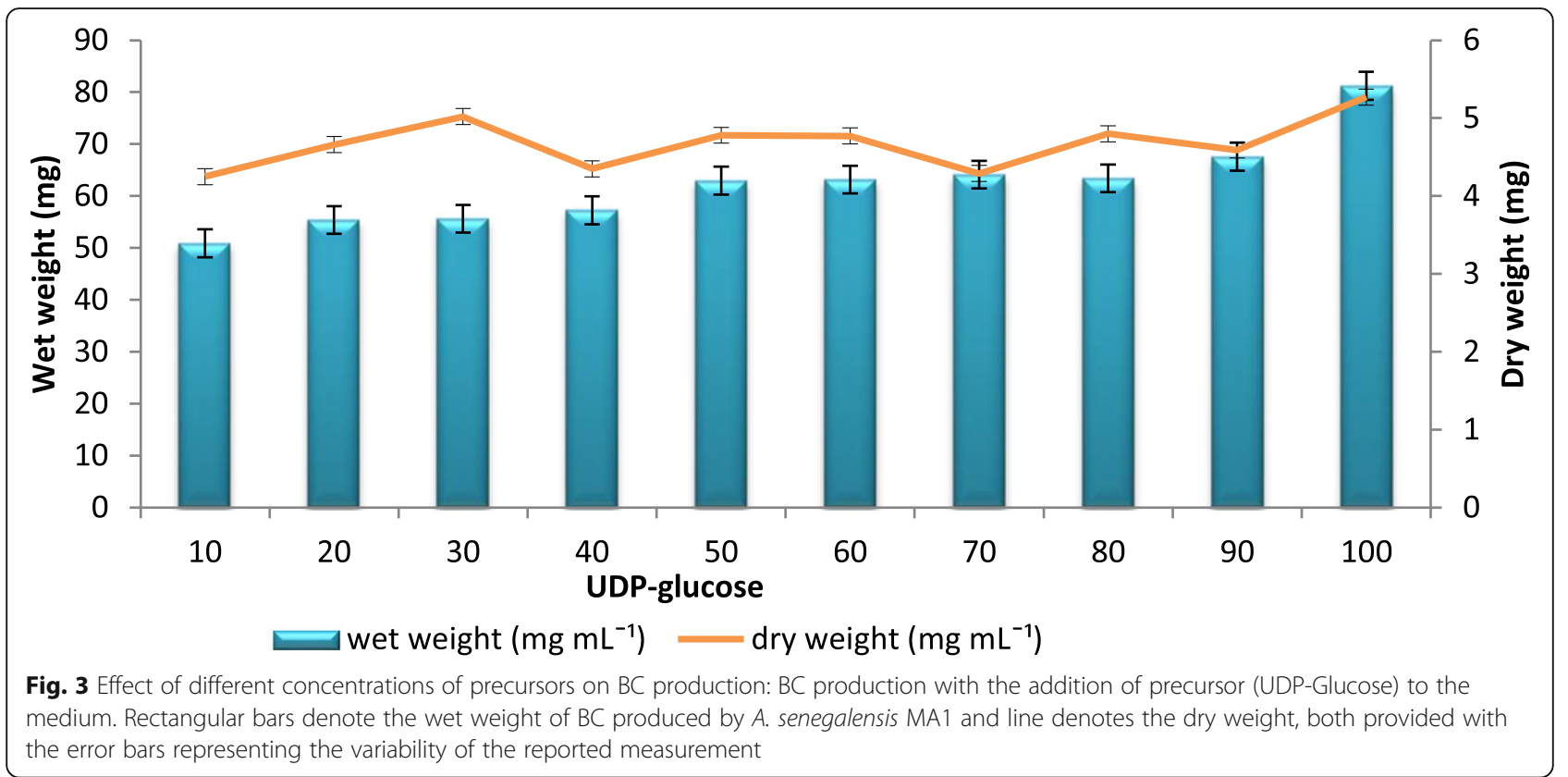

significant difference in the $\mathrm{BC}$ production at $\mathrm{pH} 5.5$, 6.0, 6.5, 7.0, 7.5, and 8.0.

Different temperatures, viz., $25^{\circ} \mathrm{C}, 27.5^{\circ} \mathrm{C}, \quad 30^{\circ} \mathrm{C}$, $32.5^{\circ} \mathrm{C}, 35^{\circ} \mathrm{C}$ and $37^{\circ} \mathrm{C}$ were evaluated for maximum production of $\mathrm{BC}$ by $A$. senegalensis MA1. The maximum BC production was observed at $37^{\circ} \mathrm{C}$ of about $57 \mathrm{mg} \mathrm{mL}^{-1}$ of wet weight and $5.21 \mathrm{mg} \mathrm{mL}^{-1}$ of dry weight. Distinct variations in the wet and dry weight of $\mathrm{BC}$ were found at different temperatures. At $35^{\circ} \mathrm{C}$, the $\mathrm{BC}$ production was
$52 \mathrm{mg} \mathrm{mL}^{-1}$ wet and $4.22 \mathrm{mg} \mathrm{mL}^{-1}$ dry weight. As the temperature decreases, the amount of $\mathrm{BC}$ produced also gets decreased at $30^{\circ} \mathrm{C}, 27.5^{\circ} \mathrm{C}$, and $25^{\circ} \mathrm{C}$ (Fig. 6).

\section{Inoculum concentration and incubation time on BC production}

The highest-level of $\mathrm{BC}$ production was achieved with $20 \%$ of inoculum concentration, i.e., at $0.545 \mathrm{OD}$, which corresponds to $395 \mathrm{~g} \mathrm{~L}^{-1}$ of wet weight and $15 \mathrm{~g} \mathrm{~L}^{-1}$ of

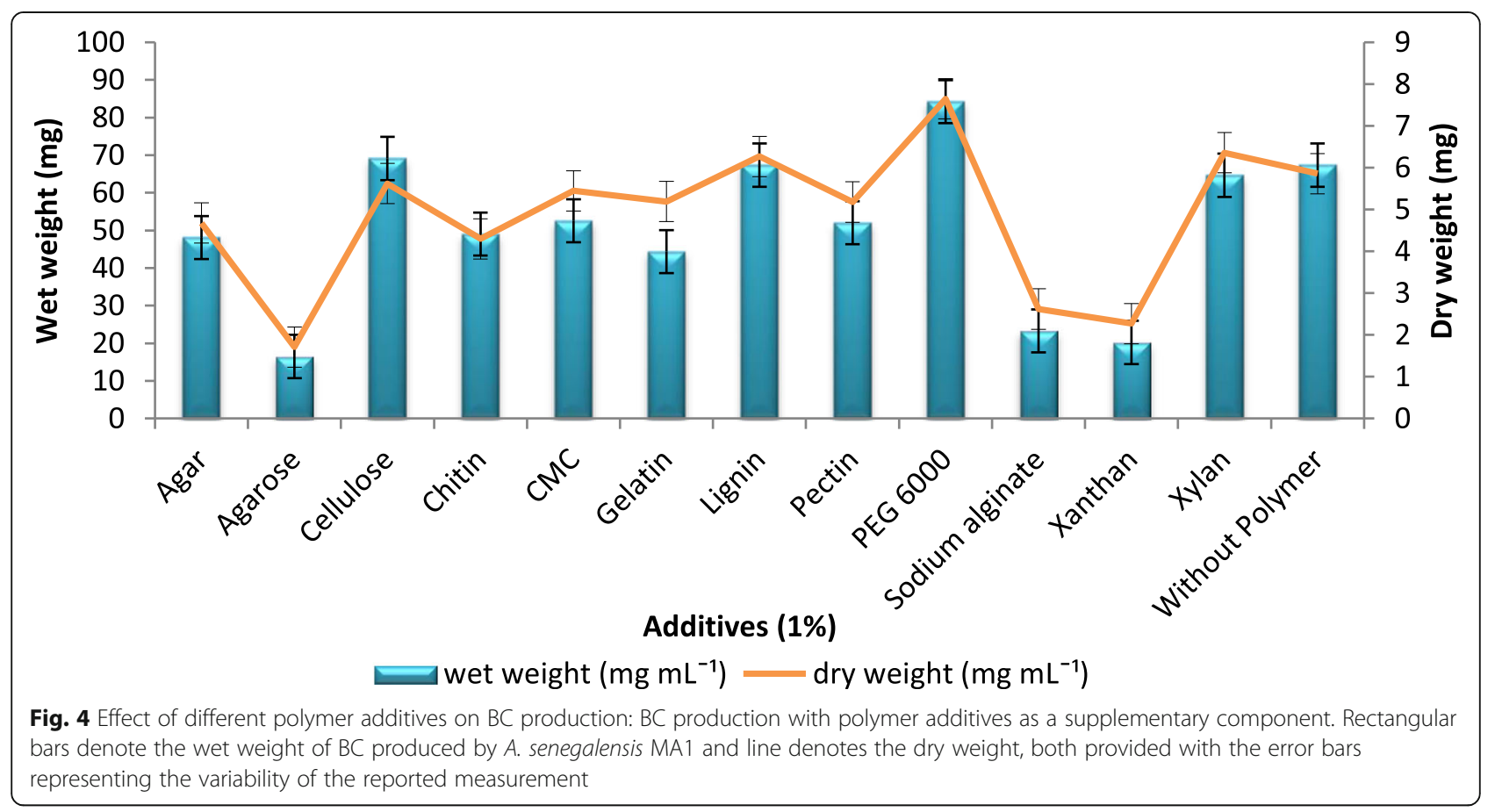




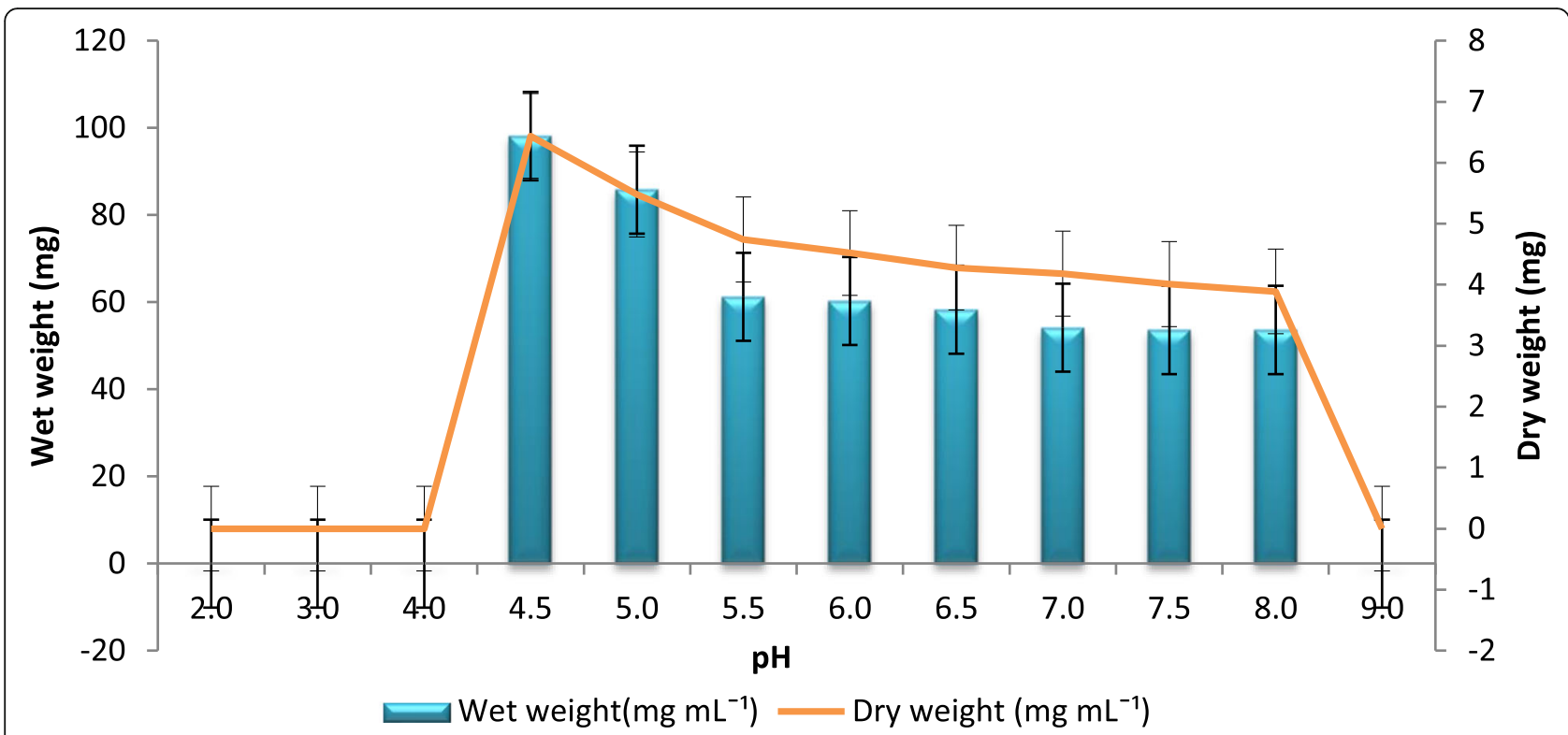

Fig. 5 Effect of different pH values on BC production: BC production at different pH, ranging from 2.0 to 9.0. Rectangular bars denote the wet weight of $B C$ produced by $A$. senegalensis MA1 and line denotes the dry weight, both provided with the error bars representing the variability of the reported measurement

dry weight. Further, at low inoculum concentration, bacterial cellulose yield was also low (Fig. 7). The concentrations of 5,7 , and $10 \%(0.227,0.326$, and 0.351 OD respectively) did not show a significant difference in the production of $\mathrm{BC}$. The lowest production levels of $279 \mathrm{~g} \mathrm{~L}^{-1}$ wet weight and $10.91 \mathrm{~g} \mathrm{~L}^{-1}$ dry weight were obtained with an inoculum concentration of $1 \%$ (0.076 OD).
The $\mathrm{BC}$ production by $A$. senegalensis MA1 was evaluated by incubating for different periods, and the results implied that maximum production recorded at 30 $\mathrm{d}$ after incubation registering about $443 \mathrm{~g} \mathrm{~L}^{-1}$ of wet weight and $17 \mathrm{~g} \mathrm{~L}^{-1}$ of dry weight. The $\mathrm{BC}$ production gradually increased with an increase in the incubation period, and a rapid increase was found at $15 \mathrm{~d}$ after inoculation (Fig. 8).

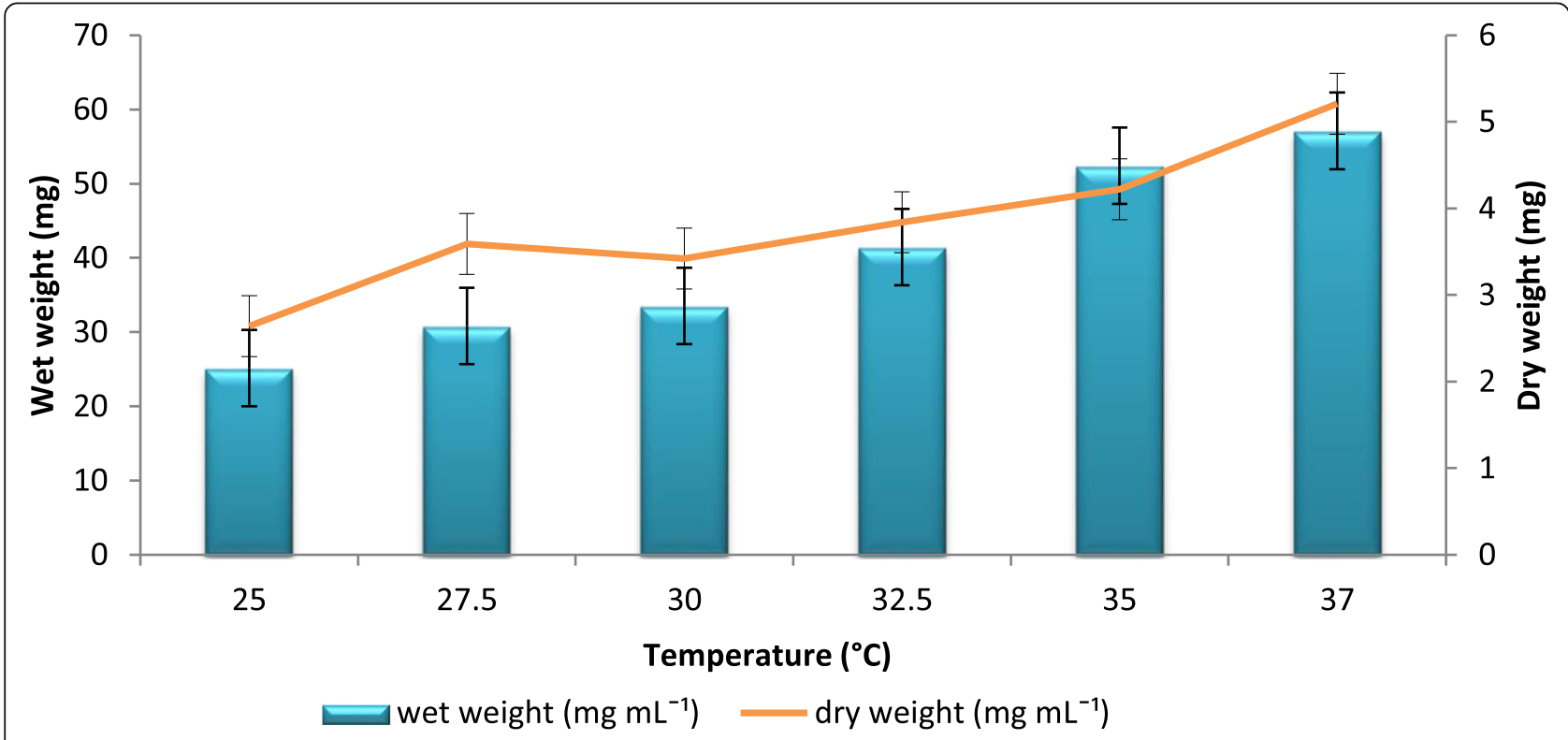

Fig. 6 Effect of different temperatures on $\mathrm{BC}$ production: $\mathrm{BC}$ production at different temperature conditions from $25^{\circ} \mathrm{C}$ to $37^{\circ} \mathrm{C}$. Rectangular bars denote the wet weight of $\mathrm{BC}$ produced by $\mathrm{A}$. senegalensis MA1 and line denotes the dry weight, both provided with the error bars representing the variability of the reported measurement 


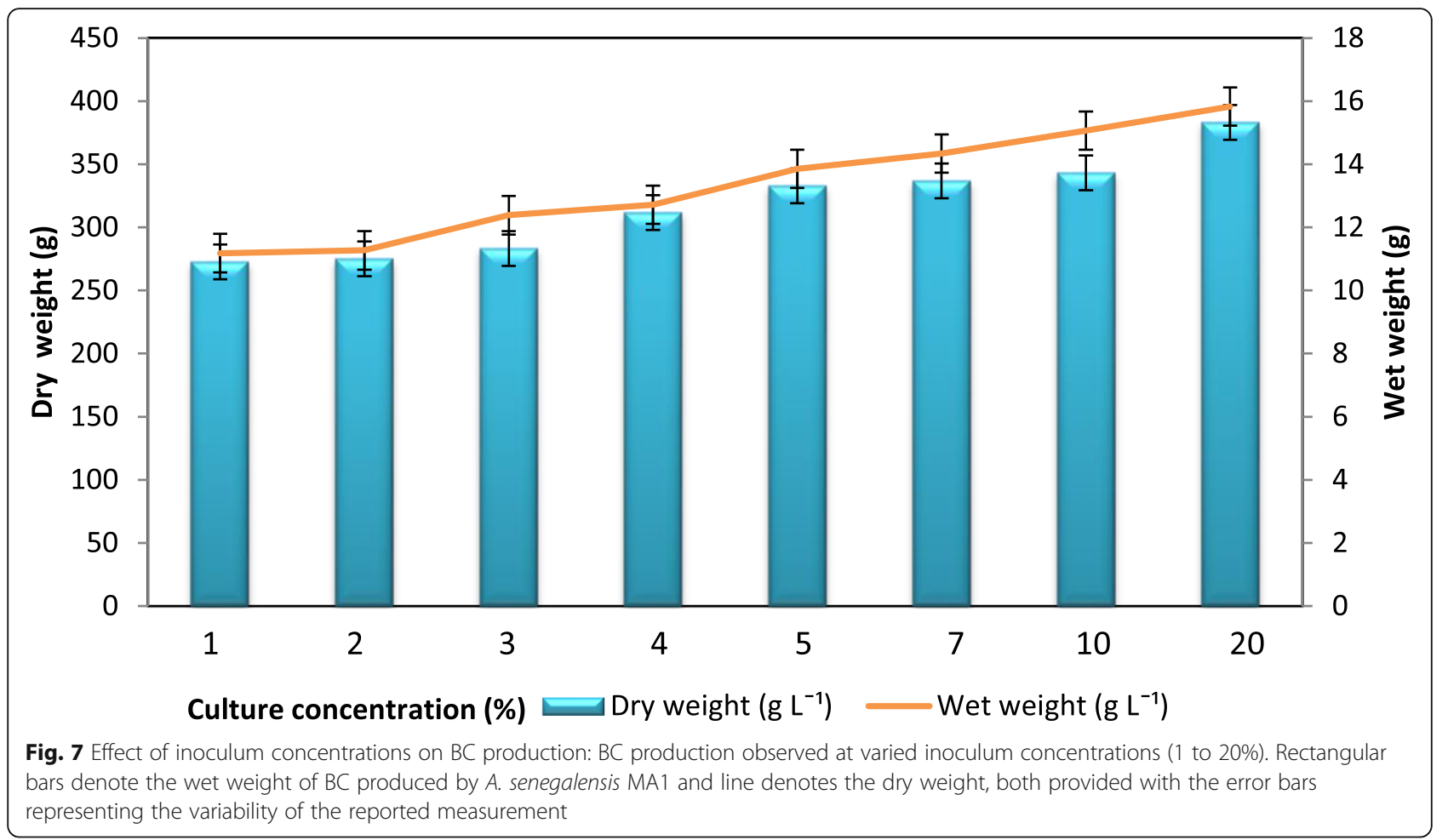

\section{Optimized culture conditions by response surface methodology (RSM)}

The culture conditions like carbon, nitrogen, $\mathrm{pH}$, temperature, precursor, and polymer additives were preoptimized and evaluated by response surface methodology using Central Composite Design (CCD). The results representing the actual and predicted values of $\mathrm{BC}$ production for optimization are given in Table 1. The design consists of a set of 50 runs each performed at different parameters and different levels. A quadratic design model was used for correlating the independent variables for optimization using the Design-Expert software version 11.0.5. The dependent variable contributes to different sets of independent variables. The $F$ value of

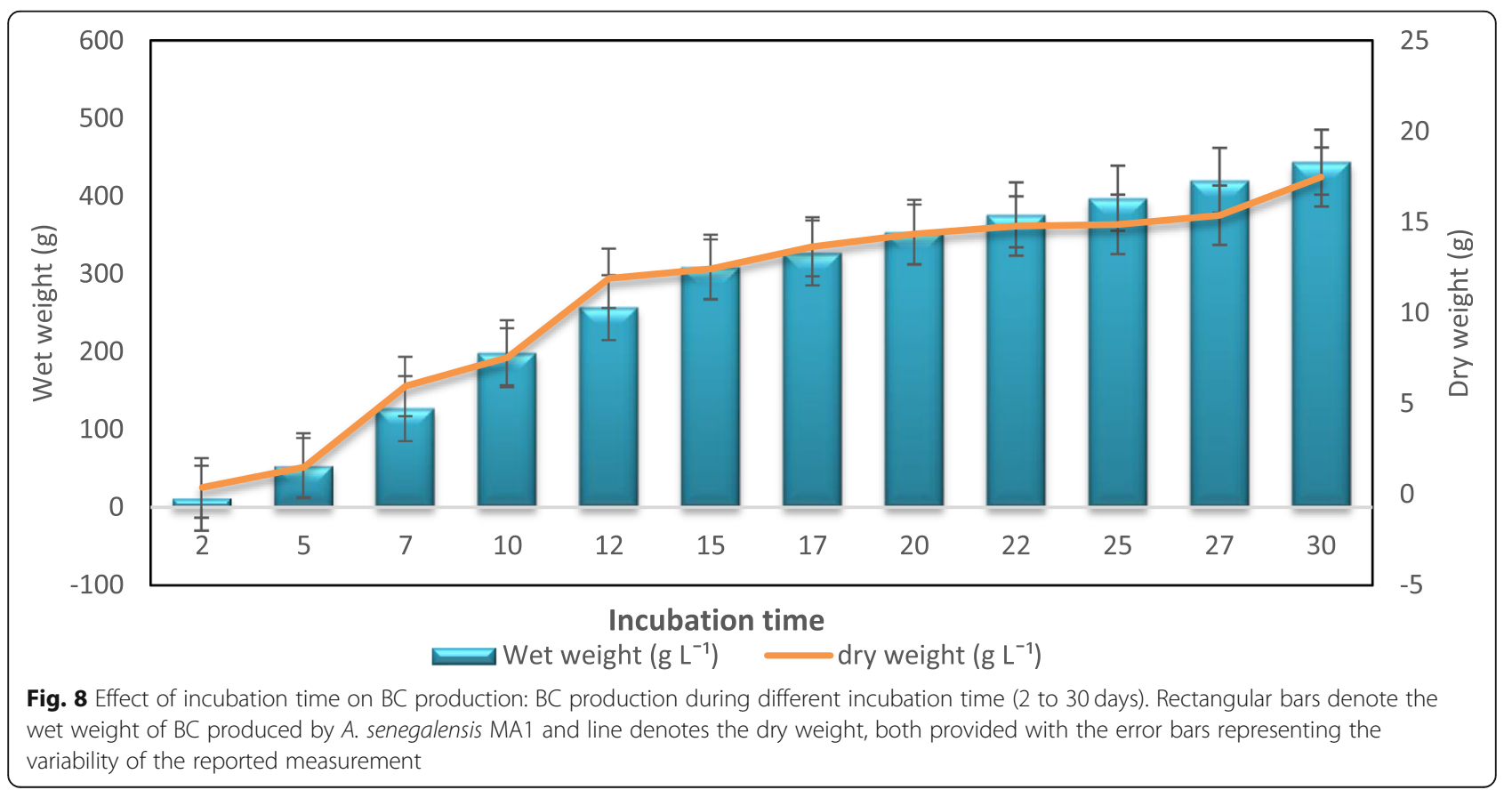


Table 1 Central Composite Design (CCD) matrix for the experimental and predicted values of wet BC produced by A. senegalensis MA1

\begin{tabular}{|c|c|c|c|c|c|c|c|}
\hline Run Order & $\begin{array}{l}\text { A: Carbon } \\
\text { (Glycerol) }\end{array}$ & $\begin{array}{l}\text { B: Nitrogen } \\
\text { (Yeast extract) }\end{array}$ & $\mathrm{C}: \mathrm{pH}$ & $\begin{array}{l}\text { D: } \\
\text { Temperature }\end{array}$ & $\begin{array}{l}\text { E: Additives } \\
\text { (PEG 6000) }\end{array}$ & $\begin{array}{l}\text { Actual wet } \\
\text { weight of BC }\end{array}$ & $\begin{array}{l}\text { Predicted wet } \\
\text { weight of } B C\end{array}$ \\
\hline & $\left(m L^{-1}\right)$ & $\left(\mathrm{g} \mathrm{L}^{-1}\right)$ & & $\left({ }^{\circ} \mathrm{C}\right)$ & $\left(\mathrm{g} \mathrm{L}^{-1}\right)$ & $\left(\mathrm{g} \mathrm{L}^{-1}\right)$ & $\left(\mathrm{g} \mathrm{L}^{-1}\right)$ \\
\hline 1 & 50.00 & 7.50 & 6.00 & 33.50 & 1.76 & 387.83 & 343.13 \\
\hline 2 & 55.00 & 5.00 & 8.00 & 37.00 & 1.00 & 0.00 & 67.06 \\
\hline 3 & 55.00 & 10.00 & 8.00 & 37.00 & 3.00 & 0.00 & 19.31 \\
\hline 4 & 45.00 & 10.00 & 4.00 & 30.00 & 3.00 & 0.00 & 244.17 \\
\hline 5 & 50.00 & 7.50 & 6.00 & 33.50 & 3.00 & 440.46 & 378.60 \\
\hline 6 & 50.00 & 7.50 & 6.00 & 33.50 & 3.00 & 418.89 & 378.60 \\
\hline 7 & 61.89 & 7.50 & 6.00 & 33.50 & 3.00 & 370.50 & 185.46 \\
\hline 8 & 45.00 & 10.00 & 4.00 & 37.00 & 1.00 & 0.00 & -53.09 \\
\hline 9 & 45.00 & 5.00 & 4.00 & 37.00 & 1.00 & 23.80 & 28.08 \\
\hline 10 & 55.00 & 10.00 & 8.00 & 30.00 & 1.00 & 22.43 & 148.3 \\
\hline 11 & 55.00 & 5.00 & 4.00 & 30.00 & 1.00 & 374.51 & 507.71 \\
\hline 12 & 55.00 & 10.00 & 4.00 & 37.00 & 1.00 & 0.00 & 92.73 \\
\hline 13 & 55.00 & 10.00 & 4.00 & 37.00 & 3.00 & 0.00 & 80.39 \\
\hline 14 & 50.00 & 7.50 & 6.00 & 33.50 & 3.00 & 394.57 & 378.60 \\
\hline 15 & 50.00 & 7.50 & 1.24 & 33.50 & 1.00 & 0.00 & -157.43 \\
\hline 16 & 45.00 & 10.00 & 4.00 & 37.00 & 1.00 & 0.00 & 41.20 \\
\hline 17 & 55.00 & 5.00 & 4.00 & 37.00 & 5.00 & 0.00 & 102.59 \\
\hline 18 & 45.00 & 5.00 & 4.00 & 37.00 & 1.00 & 0.00 & 8.60 \\
\hline 19 & 50.00 & 7.50 & 6.00 & 33.50 & 3.00 & 436.37 & 378.60 \\
\hline 20 & 45.00 & 10.00 & 8.00 & 37.00 & 1.00 & 0.00 & 76.91 \\
\hline 21 & 50.0 & 7.50 & 6.00 & 25.18 & 3.00 & 430.41 & 361.36 \\
\hline 22 & 45.00 & 5.00 & 4.00 & 37.00 & 1.00 & 0.00 & 8.60 \\
\hline 23 & 55.00 & 10.00 & 4.00 & 37.00 & 5.00 & 0.00 & 45.14 \\
\hline 24 & 45.00 & 5.00 & 4.00 & 30.00 & 5.00 & 415.10 & 265.81 \\
\hline 25 & 45.00 & 10.00 & 6.00 & 37.00 & 5.00 & 388.63 & 450.91 \\
\hline 26 & 55.00 & 5.00 & 8.00 & 30.00 & 5.00 & 0.00 & 182.28 \\
\hline 27 & 45.00 & 5.00 & 4.00 & 30.00 & 3.00 & 0.00 & 248.71 \\
\hline 28 & 45.00 & 10.00 & 4.00 & 30.00 & 1.00 & 334.97 & 92.48 \\
\hline 29 & 50.00 & 7.50 & 6.00 & 41.82 & 3.00 & 0.00 & -118.12 \\
\hline 30 & 50.00 & 7.50 & 6.00 & 33.50 & 7.76 & 469.83 & 432.62 \\
\hline 31 & 50.00 & 13.45 & 6.00 & 33.50 & 3.00 & 456.57 & 328.06 \\
\hline 32 & 45.00 & 5.00 & 4.00 & 37.00 & 1.76 & 0.00 & 28.08 \\
\hline 33 & 45.00 & 5.00 & 8.00 & 30.00 & 1.00 & 363.41 & 320.58 \\
\hline 34 & 55.00 & 5.00 & 4.00 & 37.00 & 1.00 & 386.85 & 373.54 \\
\hline 35 & 55.00 & 10.00 & 4.00 & 30.00 & 1.00 & 383.61 & 234.12 \\
\hline 36 & 45.00 & 10.00 & 4.00 & 30.00 & 5.00 & 396.92 & 372.95 \\
\hline 37 & 55.00 & 5.00 & 4.00 & 30.00 & 5.00 & 293.88 & 228.08 \\
\hline 38 & 55.00 & 5.00 & 8.00 & 30.00 & 1.00 & 383.89 & 271.63 \\
\hline 39 & 55.00 & 5.00 & 8.00 & 37.00 & 3.00 & 0.00 & 38.18 \\
\hline 40 & 50.00 & 7.50 & 10.76 & 33.50 & 3.00 & 0.00 & -18.73 \\
\hline 41 & 45.00 & 5.00 & 8.00 & 37.00 & 1.00 & 97.29 & 105.56 \\
\hline 42 & 55.00 & 10.00 & 4.00 & 30.00 & 1.00 & 0.00 & 230.50 \\
\hline
\end{tabular}


Table 1 Central Composite Design (CCD) matrix for the experimental and predicted values of wet BC produced by A. senegalensis MA1 (Continued)

\begin{tabular}{|c|c|c|c|c|c|c|c|}
\hline Run Order & $\begin{array}{l}\text { A: Carbon } \\
\text { (Glycerol) }\end{array}$ & $\begin{array}{l}\text { B: Nitrogen } \\
\text { (Yeast extract) }\end{array}$ & $\mathrm{C}: \mathrm{pH}$ & $\begin{array}{l}\text { D: } \\
\text { Temperature }\end{array}$ & $\begin{array}{l}\text { E: Additives } \\
\text { (PEG 6000) }\end{array}$ & $\begin{array}{l}\text { Actual wet } \\
\text { weight of } B C\end{array}$ & $\begin{array}{l}\text { Predicted we } \\
\text { weight of } B C\end{array}$ \\
\hline 43 & 50.00 & 7.50 & 6.00 & 33.50 & 3.00 & 378.42 & 378.60 \\
\hline 44 & 55.00 & 10.00 & 8.00 & 37.00 & 1.76 & 0.00 & -29.4 \\
\hline 45 & 50.00 & 1.55 & 6.00 & 33.50 & 3.00 & 414.57 & 355.91 \\
\hline 46 & 38.11 & 7.50 & 6.00 & 33.50 & 3.00 & 399.43 & 397.29 \\
\hline 47 & 50.00 & 7.50 & 6.00 & 33.50 & 3.00 & 408.08 & 378.68 \\
\hline 48 & 45.00 & 10.00 & 4.00 & 30.00 & 1.00 & 0.00 & 92.48 \\
\hline 49 & 50.00 & 7.50 & 6.00 & 33.50 & 1.00 & 297.98 & 343.13 \\
\hline 50 & 50.00 & 7.50 & 6.00 & 33.50 & 3.00 & 457.81 & 378.60 \\
\hline
\end{tabular}

3.77 for the model implies that the model is robust, and there is only $0.06 \%$ chance that such a large $F$ value can occur due to noise. Likewise, the $\mathrm{R}^{2}$ value of 0.7221 suggested that the model is acceptable with an adequate precision of 7.5023 , which indicates a desirable signal to noise ratio.

On the other hand, a $p$ value less than 0.0500 indicates that the model terms are significant, and the results analyzed by ANOVA for the quadratic model are shown in Table 2. The model's $F$ value was calculated as a ratio of mean square regression to the mean square residual, and the $p$ values were used to check the significance of coefficients, which represents the expected change in response per unit change in factor value keeping other factors constant (Table 3). The variation inflation factors (VIFs) denote how the coefficients of regression variance are inflated when the predictor variables are not linearly related, and VIFs less than 10 are tolerable. The final equation for $\mathrm{BC}$ production by $A$. senegalensis MA1 in terms of coded factors was given as:

Wet weight of $\mathrm{BC}=+378.60-44.53 * \mathrm{~A}-5.85 * \mathrm{~B}+$ $36.49 * \mathrm{C}-100.80 * \mathrm{D}+118.80 * \mathrm{E}-39.34 *(\mathrm{~A} * \mathrm{~B})-$

Table 2 ANOVA for quadratic model for wet weight of BC produced by A. senegalensis MA1

\begin{tabular}{|c|c|c|c|c|c|c|}
\hline Source & Sum of Squares & df & Mean Square & F-value & $\boldsymbol{p}$-value & $\overline{\text { Significance }}$ \\
\hline Model & $1.410 \times 10^{6}$ & 20 & $70,509.17$ & 3.77 & 0.0006 & Significant \\
\hline A-Carbon & $58,343.26$ & 1 & $58,343.26$ & 3.12 & 0.0886 & \\
\hline B-Nitrogen & 991.84 & 1 & 991.84 & 0.053 & 0.8195 & \\
\hline $\mathrm{C}-\mathrm{pH}$ & $34,482.34$ & 1 & $34,482.34$ & 1.84 & 0.1851 & \\
\hline D-Temperature & $2.990 \times 10^{5}$ & 1 & $2.990 \times 10^{5}$ & 15.95 & 0.0004 & \\
\hline E-Additives & $45,376.76$ & 1 & $45,376.76$ & 2.42 & 0.1303 & \\
\hline$A B$ & $43,097.43$ & 1 & $43,097.43$ & 2.3 & 0.1442 & \\
\hline$A C$ & $1.753 \times 10^{5}$ & 1 & $1.753 \times 10^{5}$ & 9.34 & 0.0048 & \\
\hline$A D$ & 7017.77 & 1 & 7017.77 & 0.375 & 0.5451 & \\
\hline$A E$ & $1.141 \times 10^{5}$ & 1 & $1.141 \times 10^{5}$ & 6.09 & 0.0197 & \\
\hline$B C$ & $32,833.07$ & 1 & $32,833.07$ & 1.75 & 0.1957 & \\
\hline $\mathrm{BD}$ & 84.84 & 1 & 84.84 & 0.0045 & 0.9468 & \\
\hline $\mathrm{BE}$ & $47,914.04$ & 1 & $47,914.04$ & 2.56 & 0.1204 & \\
\hline$C D$ & 6716.78 & 1 & 6716.78 & 0.3589 & 0.5538 & \\
\hline CE & $31,122.95$ & 1 & $31,122.95$ & 1.66 & 0.2074 & \\
\hline DE & 77.74 & 1 & 77.74 & 0.0042 & 0.9491 & \\
\hline$A^{2}$ & $13,140.61$ & 1 & $13,140.61$ & 0.7021 & 0.4089 & \\
\hline$B^{2}$ & 2315.92 & 1 & 2315.92 & 0.1237 & 0.7276 & \\
\hline$c^{2}$ & $3.916 \times 10^{5}$ & 1 & $3.916 \times 10^{5}$ & 20.89 & 0.0001 & \\
\hline$D^{2}$ & $1.145 \times 10^{5}$ & 1 & $1.145 \times 10^{5}$ & 6.09 & 0.0197 & \\
\hline$E^{2}$ & 3988.88 & 1 & 3988.88 & 0.2131 & 0.6478 & \\
\hline
\end{tabular}

$\mathrm{R}^{2}=0.7221$, Adjusted $\mathrm{R}^{2}=0.5304$, Adeq. Precision $=7.5023$ 
Table 3 Regression coefficients in terms of coded factors for optimization of cellulose production

\begin{tabular}{lllll}
\hline Factor & Coefficient Estimate & df & Standard Error & VIF \\
\hline Intercept & 378.60 & 1 & 45.72 & \\
A-Carbon & -44.53 & 1 & 25.22 & 1.47 \\
B-Nitrogen & -5.85 & 1 & 25.42 & 1.50 \\
C-pH & -36.49 & 1 & 26.88 & 1.54 \\
D-Temperature & -100.81 & 1 & 25.42 & 1.46 \\
E-Additives & -118.84 & 1 & 76.32 & 1.51 \\
AB & -39.34 & 1 & 25.93 & 1.15 \\
AC & -86.99 & 1 & 28.46 & 1.30 \\
AD & 16.48 & 1 & 26.92 & 1.24 \\
AE & -200.23 & 1 & 81.14 & 1.39 \\
BC & 37.56 & 1 & 28.36 & 1.32 \\
BD & -1.80 & 1 & 26.78 & 1.23 \\
BE & 132.81 & 1 & 83.80 & 1.45 \\
CD & -17.6 & 1 & 29.38 & 1.43 \\
CE & 113.14 & 1 & 87.74 & 1.70 \\
DE & 5.16 & 1 & 80.12 & 1.35 \\
A $^{2}$ & -15.42 & 1 & 18.41 & 1.06 \\
B $^{2}$ & -6.47 & 1 & 18.41 & 1.06 \\
C $^{2}$ & -85.58 & 1 & 18.72 & 1.11 \\
D $^{2}$ & -45.43 & 1 & 18.41 & 1.06 \\
E $^{2}$ & -64.79 & 140.34 & 1.20 \\
\hline & & &
\end{tabular}

$86.99 *(A * C)+16.48 *(A * D)-200.23 *(A * E)+$ $37.56 *(B * C)-1.80 *(B * D)+132.81 *(B * E)-17.60$ $*(C * D)+113.14 *(C * E)+5.16 *(D * E)-15.42 *$ $\mathrm{A}^{2}-6.47 * \mathrm{~B}^{2}-85.58 * \mathrm{C}^{2}-45.43 * \mathrm{D}^{2}-64.79 * \mathrm{E}^{2}$.

The final equation in terms of actual factors for production of BC by $A$. senegalensis MA1 was denoted as:

Wet weight of $\mathrm{BC}=-8134.02085+122.28 *$ Glycerol concentration $+98.89 *$ Yeast extract concentration + $702.13 * \mathrm{pH}$ of the medium $+188.28 *$ Temperature of incubation $+297.57 *$ PEG 6000 concentration -3.15 * (Glycerol concentration * Yeast extract concentration) $8.70 *$ (Glycerol concentration * $\mathrm{pH}$ of the medium $)+$ $0.94 *$ (Glycerol concentration * Temperature of incubation) $-8.42 *$ (Glycerol concentration* PEG 6000 concentration $)+7.51 *$ (Yeast extract concentration * $\mathrm{pH}$ of the medium) $-0.21 *$ (Yeast extract concentration * Temperature of incubation) $+11.17 *$ (Yeast extract concentration * PEG 6000 concentration) $-2.51 *(\mathrm{pH}$ of the medium * Temperature of incubation $)+11.89 *(\mathrm{pH}$ of the medium * PEG 6000 concentration $)+0.31$ * (Temperature of incubation * PEG 6000 concentration) - $0.62 *$ (Glycerol concentration * Glycerol concentration) $-1.04 *$ (Yeast extract concentration * Yeast extract concentration) $-21.40 *(\mathrm{pH}$ of the medium * $\mathrm{pH}$ of the medium) $-3.71 *$ (Temperature of incubation
* Temperature of incubation) - 2.86 (PEG 6000 concentration * PEG 6000 concentration).

The 3-dimensional response surface curves of different parameters are graphically represented in Fig. 9. The interaction between glycerol concentration and $\mathrm{pH}$ of the medium showed that the maximum production of $\mathrm{BC}$ could be obtained when $\mathrm{pH}$ is slightly acidic with 50 $\mathrm{mL} \mathrm{L}^{-1}$ of glycerol (Fig. 9a). In the interaction between glycerol concentration and temperature of incubation, the former has only a little influence compared to the latter (Fig. 9b). Further, the interaction between PEG 6000 concentration and glycerol concentration (Fig. 9c) indicates that the maximum concentration of additive (PEG 6000) along with glycerol could produce the maximum amount of cellulose. The effect of yeast extract concentration in interaction with the $\mathrm{pH}$ of the medium produced maximum $\mathrm{BC}$ at slightly acidic $\mathrm{pH}$ and $7.5 \mathrm{~g}$ $\mathrm{L}^{-1}$ of yeast extract (Fig. 9d). Accordingly, the interaction of $\mathrm{pH}$ with temperature increased the production to a maximum at $30{ }^{\circ} \mathrm{C}$ and $\mathrm{pH}$ of 5.0 (Fig. 9e). The interaction of PEG 6000 concentration with the $\mathrm{pH}$ of the medium and incubation temperature, respectively, revealed that the concentration of PEG 6000 had a higher impact than the other two (Fig. 9f and Fig. 9g). The interaction between the temperature of incubation and yeast extract concentration indicated that maximum $\mathrm{BC}$ was produced at a temperature of about $30^{\circ} \mathrm{C}$ with $5 \mathrm{~g} \mathrm{~L}^{-1}$ of yeast extract (Fig. 9h). The effect of PEG 6000, along with yeast extract concentration, was found to be high at a medium concentration of both the sources (Fig. 9i). Also, the effect of glycerol and yeast extract concentration had no significant differences in BC production when the other factors are constant (Fig. 9j). Ultimately, the maximum production of about $469.83 \mathrm{~g} \mathrm{~L}^{-1}$ of wet $\mathrm{BC}$ was achieved with the parameters viz., $50 \mathrm{~mL}$ $\mathrm{L}^{-1}$ of glycerol, $7.50 \mathrm{~g} \mathrm{~L}^{-1}$ of yeast extract at $\mathrm{pH} 6.0$ by incubating at a temperature of $33.5^{\circ} \mathrm{C}$ along with $7.76 \mathrm{~g}$ $\mathrm{L}^{-1}$ of PEG 6000.

\section{Discussion}

Cellulose is synthesized by bacteria belonging to the genera Acetobacter, Rhizobium, Agrobacterium, and Sarcina [25]. The most efficient producer of BC is a Gram-negative, acetic acid bacterium, Acetobacter xylinum (reclassified as Gluconacetobacter xylinus) [26, 27]. In this study, $A$. senegalensis MA1, isolated previously [28] from sugarcane juice, was used for optimizing BC production. Our earlier results demonstrated that $A$. senegalensis MA1 produced the maximum amount of cellulose mat, registering $7.2 \mathrm{~g} \mathrm{~L}^{-1}$ on a dry weight basis in HS broth in 2 weeks of culturing [28]. Although the standard recommended medium for the $\mathrm{BC}$ production is HS medium [29], researchers have continuously attempted to optimize the media and process parameters 


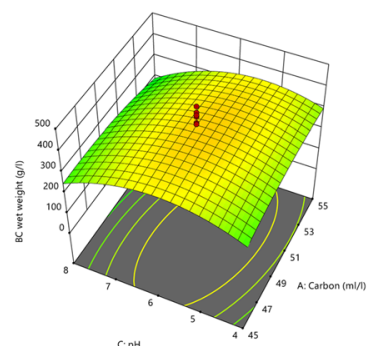

a

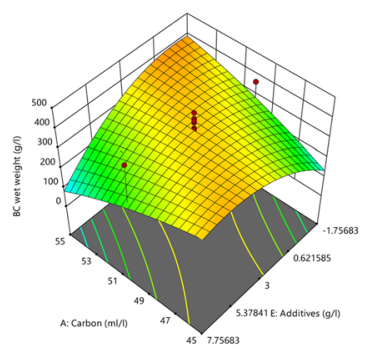

c

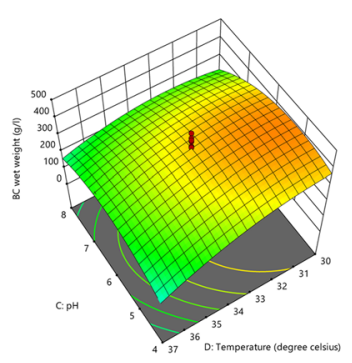

e

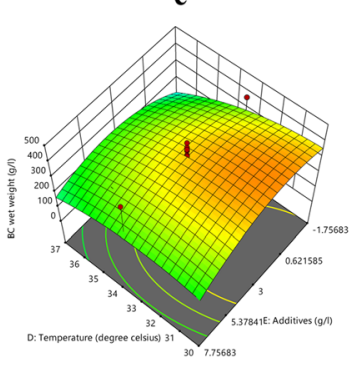

g

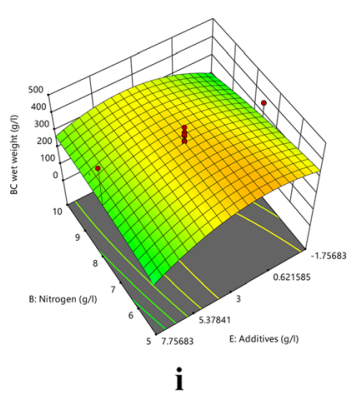

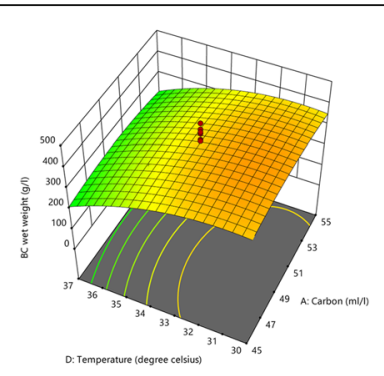

b
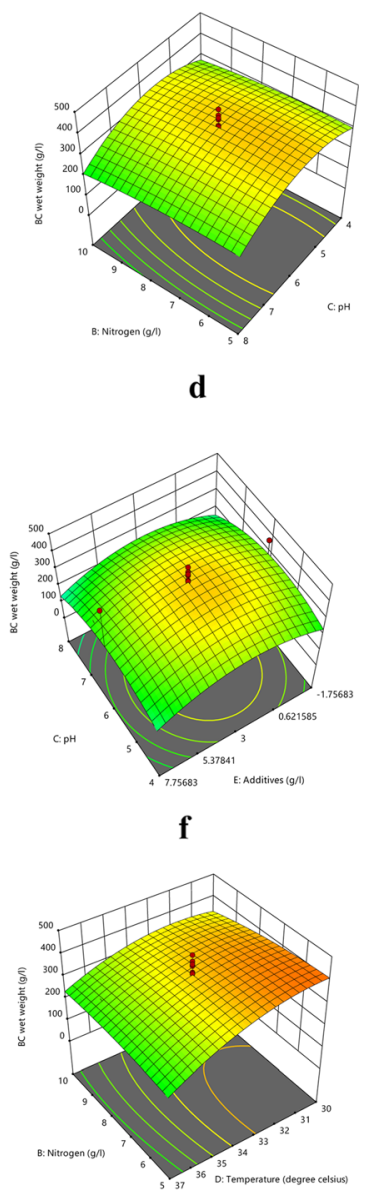

h

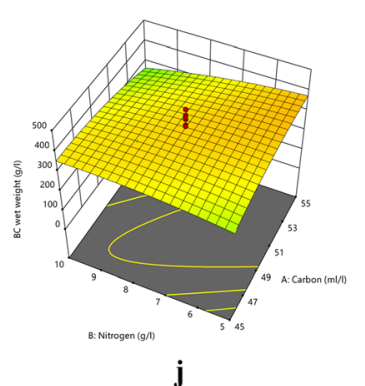

Fig. 9 (See legend on next page.) 
(See figure on previous page.)

Fig. 9 Response surface curves showing the effect of different culture conditions on BC production by A. senegalensis MA1: The response surface curves showing interaction between varying factors. Interactive effect is represented with the color ranging from green to red, green being lesser significant, and red being highly significant. 9a. Interaction between glycerol and pH; 9b. Interaction between glycerol and temperature; 9c. Interaction between PEG 6000 and glycerol; 9 d. Interaction between yeast extract and pH; 9e. Interaction between pH and temperature; $9 \mathrm{f}$. Interaction between temperature and PEG 6000; $9 \mathrm{~g}$. Interaction between yeast extract and PEG 6000; $9 \mathrm{~h}$. Interaction between yeast extract and glycerol

for improving BC yields [30]. In general, a medium containing appropriate carbon and nitrogen sources is most supportive in the stable production of $\mathrm{BC}$ [31]. The present study optimized culture conditions such as carbon, nitrogen, $\mathrm{pH}$, temperature, precursors, polymer additives, inoculum concentration, and incubation time. Although glycerol was identified as the best carbon source for maximum $\mathrm{BC}$ production by $A$. senegalensis MA1 in the present investigation, one of the previous studies identified mannitol as the best carbon source among the evaluated carbon sources [32]. Similarly, some experimental evidence suggests that the use of tricarbon sugar also increased BC production [33]. Tea broth, along with a sucrose concentration of $90 \mathrm{~g} \mathrm{~L}^{-1}$, resulted in $66.9 \%$ yield of $\mathrm{BC}$ [34].

Contrary to this, a combination of sugars such as glucose and fructose accelerated the fermentation process and maximized the yield of cellulose in lesser time [35]. Independent of the substrate used, the efficient cellulose production by the bacterium Gluconacetobacter sp. lies in its ability to synthesize glucose from the different carbon sources, followed by its polymerization to cellulose [36]. The synthesis of $\mathrm{BC}$ is a precisely and specifically regulated multi-step process that includes the synthesis of UDP-Glc, which is the cellulose precursor, followed by glucose polymerization into the $\beta$-1,4-glucan chain, and nascent chain association to form the characteristic ribbon-like structure, composed of hundreds or even thousands of individual cellulose chains [37]. In the present study, a yield enhancement in $\mathrm{BC}$ was seen by the incorporation of UDP-Glc as a precursor. Furthermore, depending on the carbon compound available (hexoses, glycerol, dihydroxyacetone, pyruvate, and dicarboxylic acids), the cells would begin Krebs cycle, gluconeogenesis, or pentose phosphate cycle, accounting to the production of UDP-Glc, which is a precursor for cellulose biosynthesis [38]. Several carbon compounds can be converted into cellulose with an efficiency of $50 \%$ by A. xylinum [39]. Supplementing the medium with ethanol instead of glucose increased the production of $\mathrm{BC}$ by serving as an energy source for ATP generation rather than being utilized as a carbon source [40]. On the other hand, during the utilization of glucose, gluconic acid is formed as a byproduct, which decreases the production of cellulose by reducing the $\mathrm{pH}$ of the culture medium. The bacterial cells cannot survive in the highly acidic medium, which hampers further production of $\mathrm{BC}$. The formation of gluconic acid can be diminished in the presence of lignosulfonate [41].

Nevertheless, the microscopic and molecular characteristics of the $\mathrm{BC}$ remain indistinguishable with any carbon source. Evidence suggested that there is no specific pattern for a given bacterial species to utilize any desired carbon and nitrogen sources for BC production [42]. In the present investigation, yeast extract yielded maximum BC. While supplementing additional nitrogen increased biomass production but diminished the cellulose production [43]. Hence, adding nitrogen source in excess amount leads to decreased $\mathrm{BC}$ production, whereas the precursor molecules such as amino acids and methionine enhanced the yield [44]. The inorganic nitrogen sources in culture medium inhibited cell growth, resulting in low BC production. Whereas, the use of organic nitrogen at sufficient concentration improved the $\mathrm{BC}$ yield. To prevent clumping and coagulation of $\mathrm{BC}$, water-soluble polysaccharides such as agar [45], acetan, and sodium alginate [46] were added as additives that enhanced the $\mathrm{BC}$ production in the jar-fermentor or airlift bioreactor. The highest production of $\mathrm{BC}\left(8.2 \mathrm{~g} \mathrm{~L}^{-1}\right)$ was established with the addition of CMC [47]. Under static conditions, the negatively charged water-soluble cellulose derivatives, $\mathrm{CMC}$, agar, and sodium alginate were used to improve the production of BC [48]. Similarly, the addition of agar at a concentration of $0.6 \%$ in the stirred-tank reactor generated $11.6 \mathrm{~g} \mathrm{~L}^{-1}$ of BC by Acetobacter xylinum BPR2001 [49]. In the present study, addition of 1\% PEG 6000 as polymer additive in $\mathrm{HS}$ medium enhanced the $\mathrm{BC}$ yield as reported earlier $[28,50]$.

Optimum $\mathrm{pH}$ is essential for oxidative reaction and normal nutrient solubility, uptake, and enhancement of $\mathrm{BC}$ production [51]. The $\mathrm{pH}$ of all media containing glucose was decreased due to the generation of gluconic acid [52]. Also, the accumulation of acetic or lactic acid in static cultures decreases the $\mathrm{pH}$ far lower than the optimal range required for good $\mathrm{BC}$ yield. The maximum cellulose yield was reported for Acetobacter pasteurianus HBB6 and Acetobacter lovaniensis $\mathrm{HBB} 5$ at $\mathrm{pH} 7.0[33,53]$.

The temperature plays a significant role in $\mathrm{BC}$ production. It has been found that $A$. xylinum culture needs a warm and static condition with the temperature not 
below $20^{\circ} \mathrm{C}$ and not above $30^{\circ} \mathrm{C}$ [54] and the ideal temperature is about $23^{\circ} \mathrm{C}$ to $30^{\circ} \mathrm{C}$. The maximum production of $\mathrm{BC}$ was found at $30^{\circ} \mathrm{C}$ by Acetobacter pasteurianus RSV-4 [31] and Komagataeibacter xylinus B12068 [55]. In another study, an optimum temperature of $30^{\circ} \mathrm{C}$ was suggested for maximum $\mathrm{BC}$ production, and at $45^{\circ} \mathrm{C}$, the lowest production was observed [56]. Acetobacter could tolerate 5 to $9 \%$ of ethanol and temperature up to $34^{\circ} \mathrm{C}$ while producing vinegar [57]. The growth of $A$. xylinum 0416 at an incubation temperature of $25^{\circ} \mathrm{C}, 27^{\circ} \mathrm{C}, 28^{\circ} \mathrm{C}$, and $30^{\circ} \mathrm{C}$ was found with no lag phase. However, at $5^{\circ} \mathrm{C}, 20^{\circ} \mathrm{C}, 35^{\circ} \mathrm{C}$, and $40^{\circ} \mathrm{C}$, the growth was prolonged with a more extended period of log phase [58]. A high incubation temperature can denature the bacterial cell components such as nucleic acids and proteins, even in an optimal growth medium.

If the inoculum concentration is in excess, there would be competition between the cells in utilizing nutrients, which disrupts the bacterial growth and thereby reduces the production of $\mathrm{BC}$ [36]. After 17-18 d of incubation, glucose in the medium was almost dissipated completely, and the metabolites reached maximum production [59]. The pellicle of $\mathrm{BC}$ is formed on the air-liquid interface of the media for providing sufficient oxygen to the bacterial cells. After $14 \mathrm{~d}$, the pellicle attains sufficient thickness, thus restricting the entry of oxygen, which makes the cells starve for oxygen and become unable to grow actively [60]. Such operational factors can be optimized by statistical approaches such as RSM to maximize the production of $\mathrm{BC}$. It can be well applied when a response or a set of responses of interest is influenced by several variables [61]. Various optimization techniques have been compared to improve the $\mathrm{BC}$ yields, such as one variable at a time and the design of experiments (DOE). The DOE being a statistical technique is helpful in analyzing the effect of process variables and the effects of their interactions. PlackettBurman design (PBD) and central composite design (CCD) have been employed for $\mathrm{BC}$ optimization [62]. However, in the present study, the initial $\mathrm{BC}$ production with A. senegalensis MA1 was only $20.4 \mathrm{~g} \mathrm{~L}^{-1}$ of wet weight and $1.02 \mathrm{~g} \mathrm{~L}^{-1}$ of dry weight, which increased to approximately 20 times after $30 \mathrm{~d}$ of inoculation by optimizing the fermentation parameters using CCD. The results showed a correlation between the predicted and experimental responses that predicted $R^{2}$ value of 0.7221 is in reasonable agreement with the adjusted $R^{2}$ of 0.5304 suggesting that the model is acceptable. Whereas, in another experiment, sucrose concentration, ethanol addition, and temperature for bacterial cellulose production were optimized by RSM for Gluconacetobacter hansenii, and it was concluded that the addition of ethanol favors oxidation into acetic acid [63]. Taguchi method of
RSM was used for optimizing the yield of bacterial cellulose and illustrated that $5 \%$ of glucose at $\mathrm{pH} 4.5$ could increase the yield up to $37.5 \%$ [64]. With $10.8 \%$ sugarcane molasses and $12.5 \%$ corn steep liquor at $31^{\circ} \mathrm{C}$ and $\mathrm{pH} 6.5$, after $172 \mathrm{~h}$, the maximum optimized production of $\mathrm{BC}$ by Gluconacetobacter xylinus $\mathrm{C} 18$ was attained [65]. Furthermore, the BC yield accomplished by Komactobacter intermedius after RSM analysis by modifying the HS medium components with $41 \mathrm{~g} \mathrm{~L}^{-1}$ of fructose, and $38 \mathrm{gL}^{-1}$ of peptone was $382 \%$ higher than the standard medium [66]. Acetobacter xylinum produced 3.6 times more yield than the conventional one by using the fermentation condition of $29.2^{\circ} \mathrm{C}, \mathrm{pH} 5.83$, and 1.75 $\mathrm{g} \mathrm{L}^{-1}$ glucose concentration, where $17.81 \mathrm{~g}$ of $\mathrm{BC}$ was achieved after optimization [67].

\section{Conclusions}

Bacterial cellulose is a versatile biomaterial and has found applications in many processes giving products like high-quality paper, nanocomposites, wound repair materials, and even artificial blood vessels. Despite various applications, the cost of manufacturing of $\mathrm{BC}$ limits its use to a few biomedical devices and traditional fermented products, including Nata de Coco, in Asian countries. Response Surface Methodology performed by using Central Composite Design (CCD), optimized various fermentation parameters and the modification of HS medium with $50 \mathrm{~mL} \mathrm{~L}^{-1}$ of glycerol, $7.50 \mathrm{~g} \mathrm{~L}^{-1}$ of yeast extract at $\mathrm{pH} 6.0$ by incubating at a temperature of $33.5^{\circ} \mathrm{C}$ along with $7.76 \mathrm{~g} \mathrm{~L}^{-1}$ of PEG 6000 for 30 days has resulted in maximum $\mathrm{BC}$ of $469.83 \mathrm{~g} \mathrm{~L}^{-1}$. A twenty-fold higher $\mathrm{BC}$ yield obtained through the optimized parameters could still be enhanced through the design of a suitable bioreactor and genetic manipulation approaches. Furthermore, $\mathrm{BC}$ produced as such is considered as a highly pure nano polymer, any interventions of nanoformulation and extending its application toward sustainable food and pharmaceutical sector would be a much appreciable way forward.

\section{Methods \\ Microorganisms and media}

The cellulose producing bacteria, A. senegalensis MA1 [28] obtained from the Department of Agricultural Microbiology, Agricultural College and Research Institute, Madurai - 625,104, was previously isolated from sugarcane juice. The isolate was maintained in standard Hestrin-Schramm (HS) medium [68] composed of glucose- $20 \mathrm{~g} \mathrm{~L}^{-1}$, peptone- $5 \mathrm{~g} \mathrm{~L}^{-1}$, yeast extract- $5 \mathrm{~g} \mathrm{~L}^{-1}$, disodium hydrogen phosphate $\left(\mathrm{Na}_{2} \mathrm{HPO}_{4}\right)-2.7 \mathrm{~g} \mathrm{~L}^{-1}$, citric acid- $1.15 \mathrm{~g} \mathrm{~L}^{-1}$ and agar- $20 \mathrm{~g} \mathrm{~L}^{-1}$. 
Pre-optimization of culture conditions for $\mathrm{BC}$ production To obtain maximum $\mathrm{BC}$, varying nutrients (carbon, nitrogen, precursor, and polymer additives), environment ( $\mathrm{pH}$ and temperature), inoculum rate, and incubation period were evaluated. BC gel was produced by inoculating the freshly prepared inoculum of $A$. senegalensis MA1 (10\%) in $250 \mathrm{~mL}$ Erlenmeyer flask containing 100 $\mathrm{mL}$ of sterile Modified Hestrin - Schramm (MHS) broth. After inoculation, the broth was incubated at $30 \pm 1{ }^{\circ} \mathrm{C}$ for $14 \mathrm{~d}$ under static conditions. The mat formed at air-liquid interface was harvested and purified by alkali treatment, i.e., $2 \% \mathrm{NaOH}$ at $80^{\circ} \mathrm{C}$ for $45 \mathrm{~min}$ and subsequently washed with distilled water until the $\mathrm{pH}$ of $\mathrm{BC}$ was neutralized to 7.0. Prior to purification, the harvested mats were washed with deionized water. The purified mats were later dried in a hot air oven at $45^{\circ} \mathrm{C}$ until $\mathrm{BC}$ reached constant dry weight. The concentration of peptone, $\mathrm{Na}_{2} \mathrm{HPO}_{4}$, and citric acid was kept constant, whereas glucose, yeast extract, $\mathrm{pH}$, and temperature of the standard media varied. All the experiments were carried out under static conditions.

\section{Nutritional parameters}

Glucose (2\%), in HS medium, was replaced with other carbon sources viz., acetic acid, ethanol, fructose, galactose, glucose, glycerol, glycine, inositol, lactic acid, lactose, malic acid, maltose, mannitol, mannose, methanol, oxalic acid, sorbitol, starch, succinic acid, sucrose, tryptose, tyrosine, xylitol, and xylose. Similarly, the effect of nitrogen sources viz., ammonium nitrate, beef extract, casein hydrolysate, calcium nitrate, malt extract, peptone, potassium nitrate, sodium azide, sodium nitrate, thiourea, tryptone, urea, and yeast extract was evaluated by keeping other factors constant except yeast extract $(0.5 \%)$. The major precursor for $\mathrm{BC}$ production was found to be uridine diphosphoglucose (UDP-Glc), and its effect on $\mathrm{BC}$ production was evaluated by different concentrations such as 10, 20, 30, 40, 50, 60, 70, 80, 90, and $100 \mathrm{ppm}$. Polymer additives such as agar, agarose, microcrystalline cellulose, chitin, carboxy methylcellulose, gelatin, lignin, pectin, polyethylene glycol (PEG) 6000 , sodium alginate, and xanthan were supplemented at $1 \%$ to evaluate the maximum production of $\mathrm{BC}$. A 24 h old culture of $A$. senegalensis MA1, grown for $14 \mathrm{~d}$ under static conditions at $30 \pm 1{ }^{\circ} \mathrm{C}$, was used for the evaluation of nutrients under all the conditions.

\section{Environmental parameters}

HS medium prepared at different $\mathrm{pH}$ values of 2.0, 3.0, $4.0,4.5,5.0,5.5,6.0,6.5,7.0,7.5,8.0$ and 9.0, was inoculated with $24 \mathrm{~h}$ old culture of $A$. senegalensis MA1 and incubated at $30 \pm 2{ }^{\circ} \mathrm{C}$ for $14 \mathrm{~d}$ under static conditions. The effect of different temperatures on $\mathrm{BC}$ production was also determined by incubating at temperatures of $25^{\circ} \mathrm{C}, 27.5^{\circ} \mathrm{C}, 30^{\circ} \mathrm{C}, 32.5^{\circ} \mathrm{C}, 35^{\circ} \mathrm{C}$ and $37^{\circ} \mathrm{C}$ for $14 \mathrm{~d}$.

\section{Inoculum concentrations and incubation times}

Different concentrations of $24 \mathrm{~h}$ old $A$. senegalensis MA1 viz., $1,2,3,4,5,7,10$, and $20 \%$, after measuring OD at $660 \mathrm{~nm}$ using UV-Vis Spectrophotometer (M/s. Shimadzu, Japan) were inoculated separately into $50 \mathrm{~mL}$ of HS broth at pH 5.0 and incubated at $30 \pm 1{ }^{\circ} \mathrm{C}$ for 14 $\mathrm{d}$ under static conditions. The inoculum was added at the rate of $10 \%$ and then incubated at $30 \pm 1{ }^{\circ} \mathrm{C}$ for different incubation periods viz., 2, 5, 7, 10, 12, 15, 17, 20, $22,25,27$ and $30 \mathrm{~d}$.

\section{Media optimization by response surface methodology (RSM)}

RSM was used for the design of experiments for the screening of five critical media components as independent variables. The variables were glycerol as carbon source, yeast extract as a nitrogen source, $\mathrm{pH}$, temperature, and PEG 6000 as a polymer additive. The dry weight of cellulose produced was fixed as the dependent variable. The design consists of 50 experimental trials, and the experiments were conducted in a randomized fashion at two levels of concentrations (high level and low level). A total of eight verification runs were performed to confirm the validity and accuracy of the model, and the experiments were done in triplicates under a static condition in $250 \mathrm{~mL}$ conical flasks. The natural levels and interval of variation of the independent variables in the experimental plan for the optimization of the cellulose production process are given in Table 4.

\section{Statistical analysis}

All the data presented in tables and figures were expressed as the mean \pm standard error of three replications. Statistical analysis was done as per the method of Panse (1954) [69]. Response Surface Methodology (RSM) was employed to study the effect of different independent parameters on dependent variables using the statistical software, Design Expert (Version 11.0.5). The

Table 4 Natural levels and interval of variation in the independent variables in the design of cellulose production

\begin{tabular}{|c|c|c|c|c|c|}
\hline \multirow[t]{2}{*}{ Factors } & \multirow[t]{2}{*}{ Codes } & \multicolumn{3}{|c|}{ Levels } & \multirow{2}{*}{$\begin{array}{l}\text { Interval } \\
\text { of } \\
\text { variation }\end{array}$} \\
\hline & & -1 & 0 & +1 & \\
\hline Carbon & Glycerol $\left(m L L^{-1}\right)$ & 45.0 & 50.0 & 55.0 & 5.0 \\
\hline Nitrogen & Yeast extract $\left(\mathrm{g} \mathrm{L}^{-1}\right)$ & 5.0 & 7.5 & 10.0 & 2.5 \\
\hline $\mathrm{pH}$ & & 4.0 & 6.0 & 8.0 & 2.0 \\
\hline Temperature & ${ }^{\circ} \mathrm{C}$ & 30.0 & 33.5 & 37.0 & 3.5 \\
\hline Additive & PEG $6000\left(\mathrm{~g} \mathrm{~L}^{-1}\right)$ & 0.0 & 2.5 & 5.0 & 2.5 \\
\hline
\end{tabular}


software was used for the data analysis, developing the regression models, and plotting the three-dimensional surface plots by employing multiple regression techniques [70]. The number of experiments designed by CCD is based on

$$
N=k^{2}+2 k+n
$$

where $N$ is the total number of experiments, $k$ is the number of factors studied, and $n$ is the number of replicates.

Experimental results obtained were analyzed using the response surface regression procedure of the statistical analysis system. The correlation between responses and independent variables is achieved by fitting them into the second-order polynomial equation.

$$
Y=\beta_{0}+\sum_{i=1}^{k} \beta_{i} x_{i}+\sum_{i=1}^{k} \beta_{i i} x_{i i}^{2}+\sum_{i=1}^{k} \sum_{i \neq j=1}^{k} \beta_{i j} x_{i} x_{j}+\varepsilon
$$

where $Y$ represents the responses, $k$ is the total number of independent factors, $\beta_{0}$ is an intercept, $i, i i$, and $i j$ with $\beta$ represent the coefficient values for linear, quadratic, and interaction effects, respectively, and $x_{i}$ and $x_{j}$ in the above equation show the coded levels for independent variables.

\section{Abbreviations \\ ATP: Adenosine Tri Phosphate; BC : Bacterial Cellulose; CCD: Central Composite Design; CMC: Carboxy Methyl Cellulose; DOE: Design of Experiments; HS: Hestrin and Schramm; OD: Optical Density; PBD: Plackett- Burman Design; PEG: Poly Ethylene Glycol; RSM: Response Surface Methodology; UDP-GIc: Uridine Di Phosphate Glucose; VIF: Variation Inflation Factors}

\section{Acknowledgements}

We acknowledge the Metabolomic and Proteomic Analytical Facility (MPAF) at the Tamil Nadu Agricultural University, Coimbatore, India for sharing their equipment for various analyses carried out in the present study.

\section{Authors' contributions}

SU received the research grant and conceptualized the idea. AK conducted the experiments. SU and NOG provided guidance to conduct the experiments. AK wrote the original draft. SU redrafted, reviewed, and edited the manuscript. All authors have read and approved the manuscript.

\section{Funding}

This study was funded by the Central Institute for Research on Cotton Technology, Indian Council Agricultural Research, Mumbai (Grant No. ICARCIRCOT-CRP-TNAU-01), India through a research project support to SU. The funders had no role in study design, data collection, and analysis, decision to publish, or preparation of the manuscript.

\section{Availability of data and materials}

All data of this manuscript are included in the manuscript. No separate external data source is required. Any additional information required will be provided by communicating with the corresponding author via the official mail: usiva@tnau.ac.in

\section{Ethics approval and consent to participate}

No specific permissions were required for the described studies because no human or animal subjects were involved in this research.

\section{Consent for publication}

All authors agreed to publish the content.

\section{Competing interests}

The authors declare that they have no competing interests.

Received: 7 April 2020 Accepted: 10 August 2020

Published online: 26 August 2020

\section{References}

1. Hon DNS. Cellulose: a random walk along its historical path. Cellulose. 1994; 1:1-25. https://doi.org/10.1007/BF00818796.

2. Klemm D, Schmauder HP, Heinze T. Biopolymers vol. 6. Vandamme S, de Beats, Steinbuchel A, Eds., ed Weinheim: Wiley-VCH; 2002.p.290-292.

3. Cheng KC, Catchmark JM, Demirci A. Enhanced production of bacterial cellulose by using a biofilm reactor and its material property analysis. J Biol Eng 2009a;3:12. https://doi.org/10.1186/1754-1611-3-12.

4. Pokalwar SU, Mishra MK, Manwar AV. Production of cellulose by Gluconacetobacter sp. Recent Res Sci Technol. 2010;2:14-9.

5. Shoda M, Sugano Y. Recent advances in bacterial cellulose production. Biotechnol Bioprocess Eng 2005;10:1. https://doi.org/10.1007/BF02931175.

6. Mohammad kazemi F, Azin M, Ashori A. Production of bacterial cellulose using different carbon sources and culture media. Carbohydrate Polymers. 2015;117:518-523. https://doi.org/10.1016/j.carbpol.2014.10.008.

7. McKenna BA, Mikkelsen D, Wehr JB, Gidley MJ, Menzies NW. Mechanical and structural properties of native and alkali-treated bacterial cellulose produced by Gluconacetobacter xylinus strain ATCC 53524. Cellulose. 2009;16:1047. https://doi.org/10.1007/s10570-009-9340-y.

8. Harhangi HR, Steenbakkers PJM, Akhmanova A, Jetten MSM, van der Drift C, Op den Camp HJM. A highly expressed family 1 -glucosidase with transglycosylation capacity from the anaerobic fungus Piromyces sp. E2. Biochimica et Biophysica Acta (BBA) - Gene Structure and Expression. 2002; 1574:293-303. https://doi.org/10.1016/S01674781(01) 00380-3.

9. Ndoye B, Cleenwerck I, Engelbeen K, Dubois-Dauphin R, Guiro AT, Van Trappen S, Thonart P. Acetobacter senegalensis sp. nov., a thermotolerant acetic acid bacterium isolated in Senegal (sub-Saharan Africa) from mango fruit (Mangifera indica L.). International Journal of Systematic and Evolutionary Microbiology. 2007;57:1576-1581. https://doi.org/10.1099/ijs.0. 64678-0.

10. Dutta D, Gachhui R. Nitrogen-fixing and cellulose-producing Gluconacetobacter kombuchae sp. nov., isolated from Kombucha tea. International Journal of Systematic and Evolutionary Microbiology. 2007;57: 353-357. https://doi.org/10.1099/ijs.0.64638-0.

11. Hungund BS, Gupta SG. Production of bacterial cellulose from Enterobacter amnigenus $\mathrm{GH}-1$ isolated from rotten apple. World J Microbiol Biotechnol 2010;26:1823-1828. https://doi.org/10.1007/s11274-010-0363-1.

12. Castro C, Zuluaga R, Putaux UL, Caro G, Mondragon I, Ganan P. Structural characterization of bacterial cellulose produced by Gluconacetobacter swingsii sp. from Colombian agroindustrial wastes. Carbohydr Polym 2011; 84:96-102. https://doi.org/10.1016/j.carbpol.2010.10.072.

13. Tsouko E, Kourmentza C, Ladakis D, Kopsahelis N, Mandala I, Papanikolaou S, Koutinas A. Bacterial cellulose production from industrial waste and byproduct streams. Int J Mol Sci 2015;16:14832-14849. https://doi.org/10. 3390/ijms160714832

14. Farag S, Asker MMS, Mahmoud MG, Ibrahim H, Amr A. Comparative study for bacterial cellulose production using egyptian Achromobacter sp. Soher. Research journal of pharmaceutical. Biological and Chemical Sciences. 2016; 7:954-69.

15. Chen P, Cho SY, Jin HJ. Modification and applications of bacterial celluloses in polymer science. Macromol Res 2010;18:309-320. https://doi.org/10.1007/ s13233010-0404-5.

16. Saibuatong $\mathrm{O}$, Phisalaphong M. Novo aloe vera-bacterial cellulose composite film from biosynthesis. Carbohydr Polym 2010;79:455-460. https://doi.org/10.1016/j.carbpol. 2009.08.039.

17. Dahman $Y$, Jayasuriya KE, Kalis M. Potential of biocellulose nanofibers production from agricultural renewable resources: preliminary study. Appl Biochem Biotechnol 2010;162:1647-1659. https://doi.org/10.1007/s12010010-8946-8.

18. Keshk SMAS. Bacterial cellulose production and its industrial applications. Journal of Bioprocessing and Biotechniques 2014;4:150. https://doi.org/10. 4172/21559821.1000150. 
19. Pa'e N, Zahan KA, Muhamad II. Production of biopolymer from Acetobacter xylinum using different fermentation methods. International Journal of Engineering and Technology. 2011;11:90-8.

20. Czaja W, Krystynowicz A, Bielecki S, Brown RM. Microbial cellulose-the natural power to heal wounds. Biomaterials. 2006;27:145-151. https://doi. org/10.1016/j.biomaterials. 2005.07.035.

21. Keshk S, Sameshima K. Evaluation of different carbon sources for bacterial cellulose production. African Journal of Biotechnology. 2005;4:478-482. https://doi.org/10.5897/ajb 2005.000-3087.

22. Noro N, Sugano Y, Shoda M. Utilization of the buffering capacity of corn steep liquor in bacterial cellulose production by Acetobacter xylinum. Appl Microbiol Biotechnol 2004;64:199-205. https://doi.org/10.1007/s00253-0031457-6.

23. Kouda $T$, Yano $H$, Yoshinaga F. Effect of agitator configuration on bacterial cellulose productivity in aerated and agitated culture. J Ferment Bioeng 1997;83:371-376. https://doi.org/10.1016/S0922-338X(97)80144-4.

24. Hutchens SA, Leon RV, O'Neill HM, Evans BR. Statistical analysis of optimal culture conditions for Gluconacetobacter hansenii cellulose production. Lett Appl Microbiol 2006;44:175-180. https://doi.org/10.1111/j.1472-765X.2006. 02055.x.

25. Jonas R, Farah LF. Production and application of microbial cellulose. Polym Degrad Stab 1998;59:101-106. https://doi.org/10.1016/S01413910(97)00197-3.

26. Yamada Y. Transfer of Acetobacter oboediens Sokollet et al. 1998 and Acetobacter intermedius Boesch et al. 1998 to the genus Gluconacetobacter as Gluconacetobacter oboediens comb. nov. and Gluconacetobacter intermedius comb. nov. International Journal of Systematic and Evolutionary Microbiology. 2000;50:2225-2227. https:// doi.org/10.1099/00207713-50-6-2225.

27. Yamada $Y$, Hoshino $K$, Ishikawa $T$. The phylogeny of acetic acid bacteria based on the partial sequences of $16 \mathrm{~S}$ ribosomal RNA: The elevation of the subgenus Gluconoacetobacter to the generic level. Bioscience Biotechnology and Biochemistry. 1997;61:1244-1251. https://doi.org/10.1271/bbb.61.1244.

28. Anusuya RS, Anandham R, Kumutha K, Gayathry G, Mageshwaran V, Uthandi S. Characterization and optimization of bacterial cellulose poduced by Acetobacter spp. J Environ Biol 2020:41:207-215. https://doi.org/10.22438/ jeb/41/2/MRN-994.

29. Lin SP, Huang YH, Hsu KD, Lai YJ, Chen YK, Cheng KC. Isolation and identification of cellulose-producing strain Komagataeibacter intermedius from fermented fruit juice. Carbohydr Polym 2016;151:827-833. https://doi. org/10.1016/j.carbpol.2016.06.032.

30. Yim SM, Song JE, Kim HR. Production and characterization of bacterial cellulose fabrics by nitrogen sources of tea and carbon sources of sugar. Process Biochem 2017;59:26-36. https://doi.org/10.1016/j.procbio. 2016.07.001.

31. Kumar V, Sharma DK, Bansal V, Mehta D, Sangwan RS, Yadav SK. Efficient and economic process for the production of bacterial cellulose from isolated strain of Acetobacter pasteurianus of RSV-4 bacterium. Bioresour Technol 2019;275:430-433. https://doi.org/10.1016/j.biortech.2018.12.042.

32. Raghunathan D. Production of microbial cellulose from the new bacterial strain isolated from temple wash waters. Microbiology and Applied Sciences. 2013;2:275-290. Corpus ID: 85864085.

33. Tamura H, Tokura S. Participation of tricarbon compounds on the biosynthesis of bacterial cellulose by Acetobacter xylinus. In: Book of abstracts 227th ACS National Meeting, Anaheim USA; 2004.

34. Cvetkovic DD, Markov SL. Cultivation of tea fungus on malt extract medium. Acta periodica technologica 2002;33:117-124. https://doi.org/10.2298/ APT0233117C

35. Goh WN, Rosma A, Kaur B, Fazilah A, Karim AA, Bhat R. Fermentation of black tea broth (kombucha): I. effects of sucrose concentration and fermentation time on the yield of microbial cellulose. Int Food Res J. 2012; 19:109-17.

36. Rangaswamy BE, Vanitha KP, Hungund BS. Microbial cellulose production from bacteria isolated from rotten fruit. International journal of polymer science 2015. 280784. https://doi.org/10.1155/2015/280784

37. Bielecki S, Kalinowska H, Krystynowicz A, Kubiak K, Kołodziejczyk M, De Groeve M. Bacterial NanoCellulose: A Sophisticated Multifunctional Material. Perspectives in Nanotechnology 2012; (Eds.) D. K. Miquel Gama, Paul Gatenholm CRC Press, 2016.

38. Delmer DP, Amor Y. Cellulose biosynthesis. Plant Cell 1995;7:987-1000. https://doi.org/10.1105/tpc.7.7.987. PMC 160898. PMID 7640530.
39. lannino NI De, Couso RO, Dankert MA. Lipid-linked intermediates and the synthesis of acetan in Acetobacter xylinum. J Gen Microbiol 1998;134:17311736. https://doi.org/10.1099/00221287-134-6-1731.

40. Keshk S, Sameshima K. Influence of lignosulfonate on crystal structure and productivity of bacterial cellulose in a static culture. Enzym Microb Technol 2006:40:4-8. https://doi.org/10.1016/j.enzmictec.2006.07.037.

41. Naritomi T, Kouda T, Yano H, Yoshinaga F. Effect of lactate on bacterial cellulose production from fructose in continuous culture. J Ferment Bioeng 1998;8589-8595. https://doi.org/10.1016/S0922-338X(97)80360-1.

42. Mikkelsen D, Flanagan BM, Dykes GA, Gidley MJ. Influence of different carbon sources on bacterial cellulose production by Gluconacetobacter xylinus strain ATCC 53524. J Appl Microbiol 2009;107:576-583. https://doi. org/10.1111/j.13652672.2009.04226.x.

43. Masaoka S, Ohe T, Sakota N. Production of cellulose from glucose by Acetobacter xylinum. J Ferment Bioeng 1993;75:18-22. https://doi.org/10. 1016/0922-338X(93)90171-4.

44. Son HJ, Kim HG, Kim KK, Kim HS, Kim YG, Lee SJ. Increased production of bacterial cellulose by Acetobacter sp. V6 in synthetic media under shaking culture conditions. Bioresour Technol 2003;86:215-219. https://doi.org/10. 1016/S09608524(02)00176-1. PMID 12688462.

45. Chao Y, Mitari M, Sugano Y, Shoda M. Effect of addition of water-soluble polysaccharides on bacterial production in a 50- $\mathrm{L}$ airlift reactor. Biotechnol Prog 2001;17:781-785. https://doi.org/10.1021/bp010046b.

46. Zhou LL, Sun DP, Hu LY, Li YW, Yang JZ. Effect of addition of sodium alginate on bacterial cellulose production by Acetobacter xylinum. J Ind Microbiol Biotechnol 2007;34:483-489. https://doi.org/10.1007/s10295-0070218-4. PMID 17440758.

47. Cheng KC, Catchmark JM, Demirci A. Effect of different additives on bacterial cellulose production by Acetobacter xylinum and analysis of material property. Cellulose. 2009b;16:1033-1045. https://doi.org/10.1007/ s10570-009-9346-5.

48. Takehiko I, Makoto M, Yasushi S, Makoto S. Role of water-soluble polysaccharides in bacterial cellulose production. Biotechnol Bioeng 2003; 83:474-478. https://doi.org/10.1002/bit.10690.

49. Bae S, Sugano Y, Shoda M. Improvement of bacterial cellulose production by addition of agar in a jar fermentor. J Biosci Bioeng 2004;97: 33-38. https://doi.org/10.1016/S1389-1723(04)70162-0.

50. Lu Z, Zhang Y, Chi Y, Xu N, Yao W, Sun B. Effects of alcohols on bacterial cellulose production by Acetobacter xylinum 186. World J Microbiol Biotechnol 2011;27: 2281-2285. https://doi.org/10.1007/s11274-011-0692-8.

51. Ramana KV, Tomar A, Singh L. Effect of various carbon and nitrogen sources on cellulose synthesis by Acetobacter xylinum. World J Microbiol Biotechnol 2000;16:245-248. https://doi.org/10.1023/A:1008958014270.

52. Embuscado ME, Marks JS, BeMiller JN. Bacterial cellulose. I. Factors affecting the production of cellulose by Acetobacter xylinum. Top Catal 1994;8:407418. https://doi.org/10.1016/S0268-005X(09)80084-2.

53. Coban PE, Biyik H. Effect of various carbon and nitrogen sources on cellulose synthesis by Acetobacter lovaniensis HBB5. African Journal of Biotechnology. 2011;10:5346-5354. https://doi.org/10. 5897/AJB10.1693.

54. Teoh AL, Heard G, Cox J. Yeast ecology of Kombucha fermentation. Int J Food Microbiol 2004;95:119-126. https://doi.org/10.1016/j.ijfoodmicro.2003. 12.020 .

55. Volova TG, Prudnikova SV, Sukovatyi AG, Shishatskaya El. Production and properties of bacterial cellulose by the strain Komagataeibacter xylinus B12068. Appl Microbiol Biotechnol 2018;102:7417-7428. https://doi.org/10. 1007/s00253-018-9198-8.

56. Pourramezan GZ, Roayaei AM, Qezelbash QR. Optimization of culture condition for bacterial cellulose production by Acetobacter sp. 4B-2. Biotechnology. 2009;8:150-154. https://doi.org/10.3923/biotech.2009.150. 154.

57. Maal BK, Shafiee R. Characterization of an Acetobacter strain isolated from Iranian peach that tolerates high temperatures and ethanol concentrations. World Acad Sci Eng Technol 2010;38:131-135. https://doi.org/10.5281/ zenodo.1078034.

58. Zahan KA, Nordin K, Mustapha M, Zairi M, Naqiuddin M. Effect of incubation temperature on growth of Acetobacter xylinum 0416 and bacterial cellulose production. Trans tech publications Itd. In Applied Mechanics and Materials 2015:815:3-8. https://doi.org/10.4028/www.scientific.net/AMM.815.3.

59. Hassan IA, AI-Kalifawi EJ. Factors influence on the yield of bacterial cellulose of Kombucha (Khubdat Humza). Baghdad Sci J 2014;11:1420-1428. https:// doi.org/10.21123/bsj.2014.11.3.1420-1428 
60. Ruka DR, Simon GP, Dean KM. Altering the growth conditions of Gluconacetobacter xylinus to maximize the yield of bacterial cellulose. Carbohydr Polym 2012;89:613-622. https://doi.org/10.1016/j.carbpol.2012.03.059.

61. Bezerra MA, Santelli RE, Oliveira EP, Villar LS, Escaleira LA. Response surface methodology (RSM) as a tool for optimization in analytical chemistry. Talanta. 2008;76:965-977. https://doi.org/10.1016/j.talanta.2008.05.019.

62. Bilgi E, Bayir E, Sendemir-Urkmez A, Hames EE. Optimization of bacterial cellulose production by Gluconacetobacter xylinus using carob and haricot bean. Int J Biol Macromol 2016;90:2-10. https://doi.org/10.1016/j.ijbiomac. 2016.02.052.

63. Hutchens SA, Leon RV, O'Neill HM, Evans BR. Statistical analysis of optimal culture conditions for Gluconacetobacter hansenii cellulose production. Lett Appl Microbiol 2006;44:175-180. https://doi.org/10. 1111/j.1472-765X.2006.02055.

64. Lin JH, Kuo JC, Lin YJ, Chen TY, Sung WP. Production of bacterial cellulose by Gluconacetobacter xylinus using taguchi methods. Appl Mech Mater 2011;4447:605-609. https:/doi.org/10.4028/www.scientific.net/AMM.44-47.605.

65. Singh OC, Panesar PS, Chopra HK. Response surface optimization for cellulose production from agro industrial waste by using new bacterial isolate Gluconacetobacter xylinus C18. Food Sci Biotechnol 2017;26:10191028. https://doi.org/10.1007/s10068-017-0143-x.

66. Santoso SP, Chou CC, Lin SP, Soetaredjo FE, Ismadji S, Hsieh CW, Cheng KC. Enhanced production of bacterial cellulose by Komactobacter intermedius using statistical modeling. Cellulose. 2020;27:2497-2509. https://doi.org/10. 1007/s10570-019-02961-5.

67. Sathar J. Optimization of bacterial cellulose roduction from Acetobacter xylinum by using response surface methodology (RSM). UMP: Doctoral dissertation; 2012

68. Hestrin S, Schramm M. Synthesis of cellulose by Acetobacter xylinum. 2 Preparation of freeze-dried cells capable of polymerizing glucose to cellulose. Biochem J 1954;58:345-352. https://doi.org/10.1042/bj0580345

69. Panse VG. Statistical methods for agricultural workers. New Delhi: Indian Council of Agricultural Research; 1954.

70. Montgomery DC. Design and analysis of experiments. New York, NY, USA: John Wiley \& Sons; 1991.

\section{Publisher's Note}

Springer Nature remains neutral with regard to jurisdictional claims in published maps and institutional affiliations.

Ready to submit your research? Choose BMC and benefit from:

- fast, convenient online submission

- thorough peer review by experienced researchers in your field

- rapid publication on acceptance

- support for research data, including large and complex data types

- gold Open Access which fosters wider collaboration and increased citations

- maximum visibility for your research: over $100 \mathrm{M}$ website views per year

At $\mathrm{BMC}$, research is always in progress.

Learn more biomedcentral.com/submissions 